
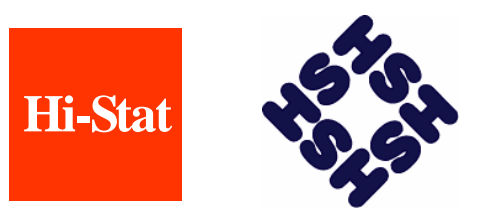

Discussion Paper Series

No.101

\title{
Policy Coordination in East Asia and across the Pacific
}

Koichiro Kamada and Izumi Takagawa

June 2005

Hitotsubashi University Research Unit for Statistical Analysis in Social Sciences A 21st-Century COE Program

Institute of Economic Research Hitotsubashi University Kunitachi, Tokyo, 186-8603 Japan http://hi-stat.ier.hit-u.ac.jp/ 
Policy Coordination in East Asia and across the Pacific

Koichiro Kamada and Izumi Takagawa

- We would like to thank participants in the Okinawa conference on the Economic Growth in EU and Asia and Comparative Econometric Analysis of Currency and Monetary Policy, especially Hajime Wago, Satoru Kano, Kazumi Asako, and Shinichi Fukuda for their valuable comments. We also thank Dale Henderson for constructive discussion and other participants in the University of Michigan October 2004 conference, especially Masahiro Kawai, Koichi Hamada, Takeo Hoshi, and Ronald McKinnon for their supportive comments. We thank Hiroshi Akama for reading and correcting one of the appendices. Any remaining errors are the authors' own, as are the opinions expressed, which should not be ascribed to the Bank of Japan, the Monetary Affairs Depatment, and the Research and Statistics Department.

*kouichirou.kamada@boj.or.jp

** izumi.takagawa@boj.or.jp 


\begin{abstract}
In this paper, we construct a macro-econometric model that describes the economic activity in the Asia-Pacific area and provide quantitative insights into the recent policy debates on monetary and currency coordination among the East Asian economies. The model includes a wide variety of monetary and currency policy rules that the East Asian economies adopt and allows for one country's policymaking to have substantial effects on foreign countries. We apply the model to three current policy issues: (1) the desirability of currency basket pegs in East Asia, (2) the anticipated effects of China's currency policy reform, and (3) the non-negativity constraint on Japanese nominal interest rates. The simulation analyses show the external economy effects of policy rules quantitatively and suggest the difficulty of monetary and currency policy coordination among the East Asian economies.
\end{abstract}




\section{INTRODUCTION}

The rapid expansion of intra-regional trade is one of the remarkable facts about recent economic developments in East Asia. ${ }^{1}$ Total exports and imports have grown faster than total production in East Asia (Figure 1.a), and intra-regional trade in East Asia has grown faster than the total trade. The share of intra-regional trade in East Asia, excluding Japan, increased from 20 percent in 1980 to 43 percent in 2002 (Figure 1.b). ${ }^{2}$

The emergence of an international production network within East Asia has contributed to this rapid expansion of intra-regional trade. ${ }^{3}$ The role of the East Asian economies in this network is to import parts and capital equipment from Japan, to trade parts and intermediate goods back and forth between themselves, and eventually to export final goods to markets such as the US and Japan. ${ }^{4}$ This international dispersion of the production process is one of the main forces driving the expansion of intra-regional trade in East Asia.

The development of an international production network has advantages and limitations for small economies like those in East Asia. By devoting their limited resources to narrow fields, the East Asian economies have been able to enhance their international competitiveness. The East Asian Miracle was achieved as the result of this mutually complementary growth among the East Asian economies. The strong interdependence among the East Asian economies, however, also worked for transmission of negative shocks. A prominent example is the Thai financial crisis of 1997, which spread and did serious damage to other East Asian economies.

The increased interdependence among the Asia-Pacific economies has created an environment in which one country's policymaking has substantial effects on others. In this context, currency-basket pegs in the East Asian economies have been recommended to stabilize their economic activity. There has also been discussion of the possibility of an Asian single currency. Recently, China’s currency

\footnotetext{
${ }^{1}$ In this paper, “East Asia” includes South Korea, Hong Kong, Singapore, and Taiwan, ASEAN (Thailand, the Philippines, Indonesia, and Malaysia), and China.

2 The share of intra-East Asian trade, including Japan, out of the total trade volume in the area increased from 35 percent in 1980 to 53 percent in 2002.

3 See Isogai, et al. (2002) for details on recent intra-East Asian trade developments.

4 East Asia has made itself as important a trading partner of Japan as the US. East Asia's share of Japanese exports increased from 26 percent in 1980 to 42 percent in 2002, while East Asia's share of the Japanese imports increased from 22 percent in 1980 to 41 percent in 2002. In contrast, the expansion of the US share of the Japanese imports was 17 percent in 1980 and unchanged in 2002, although the US share of Japanese exports rose somewhat from 24 percent in 1980 to 29 percent in 2002.
} 
policy reform has become another world concern, especially the desirability of China's policy shift from the current de facto US dollar peg to a free floating system. The purpose of our paper accordingly is to construct a multi-country macro-econometric model describing the Asia-Pacific economy and provide quantitative insights on these current policy issues.

The paper is constructed as follows. In Section 2, we build up the Asian Economy Model, which is an extension of the macro-econometric model for the Asian-Pacific area developed by Kamada, Nakayama, and Takagawa (2002) and models the Taiwan economy explicitly as a new component of "East Asia."5 In Section 3, we model a wide variety of monetary and currency policy combinations observed in the Asia-Pacific economy. Section 4 examines the basic properties of the model via simulations. Section 5 discusses three current policy issues: the desirability of currency basket pegs in East Asia, the anticipated effects of China's currency policy reform, and the non-negativity constraints on the Japanese nominal interest rates. Section 6 concludes.

\section{BASIC STRUCTURE OF THE MODEL}

In this section, we introduce the basic structure of the Asian Economy Model. The model comprises four building blocks: trade, production, prices, and policy rules. It consists of about 180 equations. We explain the first three blocks here and postpone the explanation of the policy rule block until the next section.

\section{A. Trade}

The core of the model is a set of aggregate import functions for individual countries. Import-growth rates are determined as follows:

$$
\begin{aligned}
\Delta \ln M_{i}(t)=\sum_{k=0}^{3} \alpha_{1 i k} \Delta \ln X_{i}(t+k) & \\
& +\sum_{k=0}^{3} \alpha_{2 i k} \Delta \ln D_{i}(t-k)+\sum_{k=0}^{3} \alpha_{3 i k} \Delta \ln R E_{i}(t-k),
\end{aligned}
$$

where $M_{i}$ denotes country $i$ 's aggregate imports, $X_{i}$ is aggregate exports, $D_{i}$ is domestic demand, and $R E_{i}$ is real effective exchange rate. $\Delta$ is the first-difference operator. Aggregates of imports,

\footnotetext{
${ }^{5}$ The model includes nine East Asian economies-Indonesia, Singapore, Thailand, the Philippines, Malaysia, South Korea, Hong Kong, Taiwan, and China — as well as Japan and the US. The countries that are not treated explicitly in the model constitute the "rest of the world."
} 
exports, and domestic demand are all real values and denominated in local currencies.

Equation (1) is an orthodox aggregate import function in that aggregate imports depend on domestic demand and the real effective exchange rate. A large portion of East Asia's imports consists of parts and capital or intermediate goods, which are processed into high value-added intermediate or final goods and ultimately exported back out of the country. This well-developed international production network creates a high correlation between a country's imports and exports. Another point about equation (1) is that current imports are determined by future exports, reflecting that it takes time for imported intermediate goods to be exported after being processed. ${ }^{6}$

For simplicity, we fix import shares for each country. That is, we assume that other countries’ respective shares of an individual country's imports are constant. ${ }^{7}$ Under the assumption of fixed import shares, growth rates of bilateral imports are equal to those of aggregate imports.

$$
\Delta \ln M_{j i}(t)=\Delta \ln M_{j}(t),
$$

where $M_{j i}$ denotes country $j$ 's imports from country $i$. The assumption of fixed import shares saves the time that it would take to estimate many bilateral import functions. Moreover, the assumption is roughly supported by data from a short-run perspective. When the trade structure is transformed dramatically, however, the assumption of fixed import shares appears unrealistic. In particular, confronted with the very rapid increase in China's share of Japan's imports since the 1990s, it is evident that we should take the model as only a rough approximation of reality.

Aggregate export functions are derived from the aggregate import functions. Denote country $i$ 's aggregate exports by $X_{i}$ and country $i$ 's exports to country $j$ by $X_{i j}$. Then one country's aggregate exports are given by $X_{i}(t)=\Sigma_{j} X_{i j}(t)$. Log-linearizing this relationship gives us

$$
\Delta \ln X_{i}(t)=\Sigma_{j} \theta_{i j} \Delta \ln X_{i j}(t),
$$

\footnotetext{
${ }^{6}$ Bayoumi (1996) used a VECM to analyze the international trade among the APEC economies. His model includes export volume in import functions and thus shares the same properties as our model. Two differences between the Bayoumi model and ours should be noted here. First, our model uses lead values of exports to incorporate the forward-looking factors into the model, while Bayoumi's model uses only lagged values of exports. Second, our model does not incorporate cointegration relationships between exports and imports, while Bayoumi's model assumes them in his model. Further discussion on cointegration relationships in import functions is available from the authors on request.

7 This is a difference between our model and Kamada et al. (1998), in which import shares of individual countries are allowed to vary and import functions are constructed bilaterally.
} 
In equation (3), $\theta_{i j}$ is the share of country $i$ 's exports that go to country $j\left(\theta_{i j}=X_{i j} / X_{i}\right)$, which is assumed constant, as are import shares. Notice that country $i$ 's exports to country $j$ are equal to country $j$ 's imports from country $i$. Therefore, using equation (2), we obtain growth rates of aggregate exports as follows:

$$
\Delta \ln X_{i}(t)=\Sigma_{j} \theta_{i j} \Delta \ln M_{j}(t),
$$

which tells us that each country's export-growth rate is an average of the growth rates of foreign countries' imports weighted by their export shares.

The real effective exchange rates, one of the explanatory variables in the import functions, are defined in terms of wholesale prices (or producer prices) so as to emphasize imports of production materials. ${ }^{8} \quad$ That is,

$$
\begin{aligned}
\Delta \ln R E_{i}(t)=\left\{\Delta \ln W P I_{i}(t)-\Delta \ln E_{i}(t)\right\} \\
-\Sigma_{j} \delta_{i j}\left\{\Delta \ln W P I_{j}(t)-\Delta \ln E_{j}(t)\right\},
\end{aligned}
$$

where $W P I_{i}$ denotes country $i$ 's wholesale price index, $E_{i}$ its nominal exchange rate against the US dollar (denominated in its local currency), and $\delta_{i j}$ the share of country $i$ 's imports that come from country $j \cdot{ }^{9}$

\section{A. Production}

For simplicity, the determinants of domestic demand are past income and the real long-term interest rate: ${ }^{10}$

$$
\Delta \ln D_{i}(t)=\Sigma_{k=0}^{3} \beta_{1 i k} \Delta \ln Y_{i}(t-k)-\beta_{2 i} \Delta R L_{i}(t)+\beta_{3 i} R C_{i}(t-1),
$$

where $R L_{i}$ is country $i$ 's real long-term interest rate, to be defined later. Note that the domestic demand function includes the ratio of the current account balance to potential output, $R C_{i}$, as an

\footnotetext{
${ }^{8}$ Instead of wholesale prices, consumer prices are used for China, where production-side price indices are unavailable.

${ }_{9}$ The data for the real effective exchange rates are necessary to estimate equation (2-1) and are constructed, as defined by equation (2-5). In the estimation, we treat $\delta_{i j}$ as time-variant. In the model simulation, however, we fix $\delta_{i j}$ at the year 2002 average.

${ }^{10}$ For Japan, we divide domestic demand into private demand and public demand and treat the latter as exogenous.
} 
explanatory variable. This is to model the situation in which a country's current account deteriorates and foreign investors pull out their operating capital or refrain from making new investment, thereby hindering that country's production activity. This effect is expected to be important, especially for many East Asian countries, although it is less of an issue in Japan (see Goldstein et al. (2000)).

By definition, GDP is equal to the sum of domestic demand and foreign demand, that is, $Y \equiv D+X-M . \quad$ Log-linearizing this relationship around the benchmark-year level gives

$$
\Delta \ln Y_{i}(t)=\mu_{1 i} \Delta \ln D_{i}(t)+\mu_{2 i} \Delta \ln X_{i}(t)-\mu_{3 i} \Delta \ln M_{i}(t),
$$

where $\mu_{1 i}=D_{i} / Y_{i}, \quad \mu_{2 i}=X_{i} / Y_{i}$, and $\mu_{3 i}=M_{i} / Y_{i}$, which are all fixed.

We assume that potential output follows the trend of actual output. That is, a potential growth rate is given by a two-year moving average of actual growth rates:

$$
\Delta \ln P Y_{i}(t)=\Delta \ln Y_{i}(t-8, t-1),
$$

where $P Y_{i}$ is country $i$ 's potential output and $A(t-h, t-k)$ is a moving average of variable $A$ from period $t-h$ to $t-k$. When potential output moves more slowly, the length of the moving average should be longer. ${ }^{11}$

The output gap is defined as

$$
G A P_{i}(t)=\ln Y_{i}(t)-\ln P Y_{i}(t)
$$

Note that equation (8) alone leaves the level of potential output undetermined; and the level of the output gap is also undetermined in equation (9). We calculate the level of potential output so that the output gap is averaged to zero over the course of the sample period.

The real short-term interest rate is obtained from the Fisher equation:

$$
R S_{i}(t)=I_{i}(t)-\Delta \ln C P I_{i}(t+1),
$$

\footnotetext{
${ }^{11}$ We can make the model more sensitive to external shocks by using a shorter moving average of real output as a proxy for potential output. However, since we make use of the output gap as a measure of economic welfare, a longer moving average of real output may be appropriate as a proxy for potential output.
} 
where $R S_{i}$ is country $i$ 's short-term interest rate and $C P I_{i}$ is the consumer-price index. We use the term structure model of interest rates and define the real long-term interest rate as a 2-quarter forward moving average of the real short-term interest rates:

$$
R L_{i}(t)=R S_{i}(t, t+1)
$$

Various assumptions are admissible for the length of the moving average.

Next, we define the ratio of the current account balance to potential output, which is one of the key elements in the domestic-demand functions, as described below. By definition, we have $R C \equiv(X-M) / P Y$. Log-linearizing this, we obtain:

$$
\Delta R C_{i}(t)=\lambda_{1 i} \Delta \ln X_{i}(t)-\lambda_{2 i} \Delta \ln M_{i}(t)-\lambda_{3 i} \Delta \ln P Y(t),
$$

where $\lambda_{1 i}=X_{i} / P Y_{i}, \quad \lambda_{2 i}=M_{i} / P Y_{i}$, and $\lambda_{3 i}=\left(X_{i}-M_{i}\right) / P Y_{i}$, which are all fixed. It will be noted that the current-account balance is standardized by potential output rather than by actual output. This is because a country's foreign deficit should be evaluated against its ability to repay.

\section{B. Prices}

The entire structure of prices is based on wholesale prices (WPI). For country $i$, the inflation rate in wholesale prices is determined by the Phillips curve:

$$
\begin{aligned}
\Delta \ln W P I_{i}(t)=\gamma_{0 i} & +\gamma_{1 i} \Delta \ln W P I_{i}(t-1)+\gamma_{2 i} G A P_{i}(t-1) \\
& -\gamma_{3 i}\left\{\Delta \ln R E_{i}(t)-\Delta \ln W P I_{i}(t)\right\} .
\end{aligned}
$$

The current inflation rate depends primarily on past inflation rates and the output gap. A secondary effect on the inflation rate comes from import prices; we include the depreciation rate of the nominal effective exchange rate ( $\Delta \ln R E_{i}-\Delta \ln W P I_{i}$ ) as an explanatory variable for the inflation rate.

Changes in wholesale prices are transmitted into the consumer price index gradually over time. We let the inflation rate of consumer prices be a one-year moving average of the inflation rates of wholesale prices:

$$
\Delta \ln C P I_{i}(t)=\Delta \ln W P I_{i}(t-3, t) .
$$


The length of the moving average should reflect the speed at which cost changes in upstream industries are passed into price changes in downstream industries. Thus, it may be desirable to adopt different lengths of moving average across different countries.

\section{MONETARY AND CURRENCY POLICY RULES}

The exchange rate and interest rates in a country are closely linked with those in foreign countries, though controlled partly by the local monetary authority. In particular, in a country allowing free capital movements, the uncovered exchange rate parity condition implies strong international linkages between interest rates and exchange rates. Consequently, a country cannot determine its interest rates and exchange rate in isolation. In other words, one country's monetary policy, currency policy, and capital policy are subject to international restriction.

This international policy restriction is characterized by the concept of the open-economy tri-lemma, which is that the three policy goals-independent monetary policy, free capital mobility, and exchange-rate stability-cannot be achieved simultaneously. ${ }^{12}$ If a country wishes to adopt an independent monetary policy to stabilize its domestic economy, then it has to give up either exchange-rate stability or free capital movement. Similarly, if a country wishes to invite foreign capital by stabilizing its exchange rate and liberalizing its capital markets, then it has to abandon an independent monetary policy. These theoretical relationships are vital, when we construct individual countries' actual policy combinations.

We classify our eleven countries into four groups according to their existing monetary and currency policy. Policy-making in Japan and the US may be reasonably described by the Taylor rule. ${ }^{13}$ Malaysia, Hong Kong, and China can be considered to have adopted a US dollar peg exchange rate policy. Singapore, Indonesia, and Taiwan make use of a currency-basket system. Thailand, the Philippines, and South Korea adopt an inflation-targeting policy. We try to avoid excessive abstraction from the diverse policy combinations actually observed in the East Asian economies and take care to

\footnotetext{
${ }^{12}$ The open-economy tri-lemma is also called the unholy trinity, impossibility theorem, inconsistent trinity, and incompatible trinity.

${ }_{13}$ Since the zero interest rate policy (1999) and the quantitative easing policy (2001), the uncollateralized-overnight-call rate (the Japanese monetary policy instrument) has remained at the zero percent level in Japan. Clearly, the Taylor rule is not an appropriate policy rule under this situation. We return to this problem in Section 5.
} 
keep the individual characteristics of each country's actual policy-making process. Below, we first describe the monetary and currency policy rules in Japan and the US and then proceed to show what modifications are required to model the remaining countries’ policies.

\section{A. Japan and the US}

Since capital movements are free in Japan, the exchange rate should satisfy the uncovered exchange rate parity. Denote country $i$ 's nominal short-term interest rate by $I_{i}$ and the US rate by $I_{\text {us }}$. Let RISK $_{i}$ be country $i$ 's risk premium relative to the US. Then, uncovered exchange rate parity is satisfied when

$$
I_{i}(t)=I_{u s}(t)+\Delta \ln E_{i}(t+1)+R I S K_{i}(t) .
$$

The short-term interest rate is determined by the Taylor rule, according to which the monetary authority controls the nominal short-term interest rate, paying attention to the CPI inflation rate and the output gap:

$$
I_{i}(t)=C_{i}(t)+\chi_{1 i}\left\{\Delta \ln C P I_{i}(t)-\Delta \ln C P I_{i}^{*}\right\}+\chi_{2 i} G A P_{i}(t),
$$

where $\Delta \ln C P I_{i}^{*}$ denotes the steady-state rate of consumer price inflation. $\quad C_{i}$ summarizes all factors other than the inflation rate and the output gap, and it is the sum of the steady-state real interest rate, the steady-state inflation rate, and the deviation of the risk premium from its steady-state value:

$$
C_{i}(t)=R S_{i}^{*}+\Delta \ln C P I_{i}^{*}+\kappa_{i}\left\{R I S K_{i}(t)-R I S K_{i}^{*}\right\},
$$

where $R S_{i}^{*}$ is the real short-term interest rate in the steady state. ${ }^{14}$

The assumption of $\kappa_{i}=1$ in equation (17) implies that the nominal short-term interest rate rises in exactly the same amount as an increase in the risk premium for Japan. Together with equations (15) and (16), this means that the nominal exchange rate of the yen vis-à-vis the US dollar is independent of the risk premium. This relationship holds, when Japan's credit risk is properly evaluated in its domestic financial market and there is no difference in the degree of risk aversion

\footnotetext{
${ }^{14}$ Equation (17) has to hold even in the steady-state, implying the following equation: $\operatorname{RISK}_{i}^{*}=\left(R S_{i}^{*}+\Delta \ln C P I_{i}^{*}\right)-\left(R S_{u s}^{*}+\Delta \ln C P I_{u s}^{*}\right)$.

That is, the risk premium in the steady-state is equal to the difference in the steady-state nominal interest rate
} between country $i$ and the US. 
between Japan and the US. Alternatively if we suppose that Japanese investors have a smaller concern about Japan's credit risk relative to their US counterparts, this implies that $\kappa_{i}<1$. In such a case, the yen would depreciate against the US dollar. This is because the yen would have to appreciate in the future to compensate for the smaller increase in its nominal short-term interest rate. We consider the latter case when we simulate a country's risk premium shock in Section 5.

The US financial sector is almost the same as Japan's. The differences are that in the US case, it is not necessary to specify the uncovered exchange rate parity condition and that the US risk premium is zero by definition.

\section{B. East Asian Economies}

The East Asian economies adopt various combinations of monetary and currency policy as noted in Table 1. Details for each country are available from the authors on request. In addition, the extent to which capital controls remain in place differs across countries. For our purposes, we try to balance two objectives: adequate reflection of this diverse reality against the need to keep our model of monetary policy, currency policy, and capital controls as simple as possible.

\section{(i) Malaysia, China, and Hong Kong}

Consider first the US dollar peg adopted by Malaysia and China and also Hong Kong’s currency board. For Malaysia, the US dollar peg means that the ringgit is fixed against the US dollar and thus can be expressed as follows:

$$
\Delta \ln E_{i}(t)=0 .
$$

We can describe Malaysia’s exchange rate policy by replacing equation (16) with equation (18). The same relationship may be applied to the currency policies adopted by China and Hong Kong. Note that we assume away the uncovered exchange rate parity for Malaysia and China, since they maintain relatively strict capital controls in comparison to other East Asian countries. Instead, we treat the nominal interest rates in Malaysia and China as exogenous.

(ii) Singapore, Indonesia, and Taiwan

We construct Singapore's currency basket by averaging the depreciation rates of other countries' 
currencies, using their import shares as currency weights. ${ }^{15}$ To obtain Singapore's currency-basket policy, we equate the depreciation rate of the currency basket to that of the Singapore dollar:

$$
\Delta \ln E_{i}(t)=\Sigma_{j} \delta_{i j} \Delta \ln E_{j}(t)
$$

We can describe Singapore's monetary policy by replacing equation (16) with equation (19).

Indonesia is planning to adopt an inflation targeting policy, but the introduction has not yet completed. For this reason, we assume that the Indonesian government pegs the rupiah to a currency basket, consisting of the US dollar and the yen. Taiwan is a unique economy that adopts monetary-aggregate targeting. Since we have incorporated no "money" in the model, however, we treat Taiwan similarly to Indonesia. ${ }^{16}$

\section{(iii) South Korea, Thailand, and the Philippines}

Some of the East Asian countries have adopted an inflation-targeting policy (South Korea in 1998, Thailand in 2000, and the Philippines in 2002). ${ }^{17}$ Since the history of inflation-targeting policy is rather short in these countries, we have only limited knowledge of the mechanism by which they commit themselves to this policy. For this reason, we estimate the following equation:

$$
I_{i}(t)=\phi_{0 i}+\phi_{1 i} \Delta \ln C P I_{i}(t)+\phi_{2 i} \Delta \ln E_{i}(t) \text {. }
$$

That is, monetary authorities monitor not only inflation rates of consumer prices, but also depreciation rates of their currencies, since the latter are a possible cause of future inflation. ${ }^{18}$

\section{BASIC PROPERTIES OF THE MODEL}

In this section, we present the basic properties of the model by introducing external shocks. We investigate the effects of the following four types of shocks: (1) the growth rate of Japanese domestic

\footnotetext{
15 Singapore has been using a currency basket since 1981, but the weight of each currency in the basket has not been announced. We substitute import shares for currency weights for simplicity. Alternatively, we could use estimation results from Frankel and Wei (1994), Kwan (1995), and Fukuda and Ji (2001).

${ }_{16}$ We construct the target-currency basket for Indonesia and Taiwan, consisting of the Japanese yen and the US dollar with reference to Kawai (2002).

17 Thailand has adopted a managed floating currency system, which is considered to be a de facto currency basket-peg policy. Based on Kawai (2002), we construct a currency basket consisting of the Japanese yen and the US dollar.

${ }^{18}$ If the Phillips curve does not include the output gap as an explanatory variable, inflation targeting and exchange rate targeting have almost the same effects.
} 
demand decreases by 1 percent; (2) the growth rate of US domestic demand decreases by 1 percent; (3) the growth rate of East Asian domestic demand decreases by 1 percent (excluding Japan); and (4) the growth rate of Asia-Pacific domestic demand decreases by 1 percent. Key simulation results are summarized in Table 2.

\section{(i) A 1 percent decline in the growth rate of Japanese domestic demand}

First, we simulate the situation in which the growth rate of the Japanese domestic demand decreases by 1 percent per annum (a -0.25 percent decline every quarter for four quarters <periods 1 to $4>$ ). The effects on the Japanese economy are shown in Figure 2. The declines in Japanese exports are driven by three forces. First, the yen depreciation caused by the Japanese recession works to increase its exports. Second, however, the decrease in Japan's domestic demand causes a decline in its imports and thus decreases in foreign countries' exports. This results in a decrease in foreign countries' imports from Japan, i.e., a decrease in the Japanese exports. Third, the worsening of the current account causes a capital outflow from the East Asian economies, with the resulting financial restriction slowing their production activity. This shrinkage reduces demand for goods exported from Japan. The current simulation shows that the second and third forces outweigh the first forces with a consequent overall decline in Japanese exports.

The decreases in prices are also worth noting. There are two opposing forces that drive price movements in Japan. First, the depreciation of the yen puts upward pressure on Japan's price level. Second, however, prices are put under downward pressure generated by the negative output gap due to the recession. The simulation indicates that the second force is greater than the first.

Faced with a worsening of the output gap and the deflation, the monetary authority lowers the nominal short-term interest rate in accordance with the Taylor rule. Since the late 1990s, however, the short-term interest rate has already reached zero percent in Japan. Thus the monetary authority no longer has the option of lowering the short-term interest rate. In this case, the economic slump and the resulting deflation are likely to be more severe than shown in the simulation. We return to this issue in Section 5 below.

Next, for illustrative purposes, we consider the effects of the Japanese recession on the Thai economy (Figure 3). The Thai baht depreciates against the US dollar. This is a consequence of 
market investors foreseeing that the monetary authority will lower the interest rate when the negative output gap expands in the future. What is more important, however, is that the real effective exchange rate appreciates for the first two years in spite of the Thai baht depreciation, since many other countries' currencies depreciate more than the baht. Consequently, Thai exports and real GDP continue deteriorating. In addition, the decline in foreign demand leads to a decrease in the ratio of the current account balance to potential output, which impacts negatively on Thai domestic demand (see equation 6). Results for other countries covered in the model are available from the authors on request.

(ii) A 1 percent decline in the growth rate of the US domestic demand

Next, we simulate the situation in which the growth rate of US domestic demand declines by 1 percent per annum (a -0.25 percent decline every quarter for four quarters <periods 1 to $4>$ ). In Figure 4 , Japan's exports fall below their baseline by -2 percent after a year and -4 after two years (see also Table 2). Since the US is Japan's biggest export market, it is expected that a recession in the US economy has a direct impact on the Japanese economy.

Nonetheless, the magnitude of the impact is quite large, when we recall that the US share of Japan's total exports is at most 30 percent. The simulation results may thus be explained by noting that the recession in the US induces a reduction in East Asian exports to US markets; this in turn reduces Japan's exports to East Asia. At the same time, Japan experiences an appreciation of the real effective exchange rate, which squeezes its net exports further. With all these factors combined, the US demand shock produces a more than proportional effect on the Japanese economy.

Simulation results for other countries in the model are available from the authors on request.

\section{(iii) A 1 percent decline in the growth rates of the East Asian domestic demand (excluding Japan)}

We also simulate the case in which the growth rates of domestic demand decrease across all of the East Asian economies and China by 1 percent per annum (a -0.25 percent decline every quarter for four quarters <periods 1 to $4>$ ). As shown in Figure 5 and Table 2, the decrease in Japanese exports is one third of that observed in the case of the US recession scenario after a year and one fifth after two years.

These results are combined with the results obtained in the simulation of a decrease in the US domestic demand. Despite the US share of Japanese exports (30 percent) being smaller than East Asia's share (40 percent), the impact of the US demand shock on the Japanese economy is larger than the East 
Asian demand shock. This reflects the respective roles that the two economic areas play in the world economy: the US as the "world's largest consumer" and the East Asian economies as the "world factory." A decrease in domestic demand in the East Asian economies, which are not final destinations of consumption goods, has a relatively small impact on Japan, and indeed on the global economy. The results for other countries in the model are available from the authors on request.

(iv) A 1 percent decline in the growth rates of the Asia-Pacific domestic demand

As a final demand shock scenario, we simulate the situation in which the growth rates of domestic demand decrease in all of the Asia-Pacific economies by 1 percent per annum (a - -0.25 percent decline every quarter for four quarters <periods 1 to $4>$ ). The resulting effects on Japan are shown in Figure 6. As observed in Table 2, the effects of this scenario are nearly equal to the sum of the effects of the preceding three scenarios.

This simulation tells us to what extent demand shocks are amplified dynamically through the international production network developed in the Asia-Pacific region. Table 2 shows that an Asia-Pacific demand shock is amplified 1.5 times in a year and 2.5 times in two years on average. The most vulnerable country is Thailand, whose real GDP declines 2 percent in a year and more than 4 percent in two years. The table also shows that South Korea and Singapore are likely to suffer sizable decreases in real GDP, whereas the impact on Hong Kong's real GDP is relatively small.

\section{POLICY ANALYSIS}

In this section, we conduct some policy simulations, using the model. In the previous section, we explored the model's properties under the policy rules followed by the East Asian economies in 2004. As observed, the international production network developed within East Asia has created an environment in which one country's policymaking has substantial effects on other countries. In this section, we now investigate the desirability of currency-basket pegs for East Asia, the anticipated effects of China's currency reform on the Asia-Pacific region, and the spillover effects of the non-negativity constraint on Japanese nominal interest rates.

\section{A. The Desirability of Currency-Basket Pegs for East Asia}

There have been many advocates of currency-basket pegs after the Asian Currency Crisis of 1997. 
There is little quantitative evidence, however. Our purpose here is to use our econometric model to quantify the stabilization effects of currency basket pegs in East Asia.

Since it is unrealistic to examine all possible policy combinations for the nine East Asian economies, we consider two counterfactual policy regimes as well as the current regime described in Section 3. The first regime is called the US dollar peg regime, where all the economies, except for Japan and the US, peg their own currencies to the US dollar. ${ }^{19}$ This regime is broadly consistent with the situation before the 1997 Asian Currency Crisis. As history demonstrates, it was not only a key determinant of the East Asian Miracle, but also proved to be instrumental in compounding the effects of the crisis. The second policy regime is called the currency-basket regime, where all the economies, except Japan and the US, peg their currencies to their respective currency baskets. Here we assume that the East Asian economies construct their own currency baskets with import shares as currency weights. $^{20}$

To evaluate policy regimes, we have constructed three scenarios: (1) Thai demand and risk premium shocks, (2) US demand shock, and (3) Japanese risk premium shock. When investigating the effects of the Thai demand and risk premium shocks, we have in mind the 1997 Asian Currency Crisis, which was initiated by a speculative attack on the Thai baht and subsequently had negative impacts on real economic activity. Second, when examining the effects of the US demand shock, we consider the IT recession originating in the US in 2001 for instance. The deterioration of US high-tech industries was transmitted to the East Asian economies, amplified in their production network, and spilled over to dampen world economic growth eventually. Third, when most East Asian economies pegged their own currencies to the US dollar before the 1997 Asian Currency Crisis, a Japanese risk premium shock created a fluctuation in the yen/dollar exchange rate and thus economic turbulence in the East Asian economies.

To examine the Thai demand and risk premium shocks, we assume a 10 percent decline in the

\footnotetext{
${ }^{19}$ Remember that Malaysia, Hong Kong, and China currently employ the US dollar peg policy. Therefore, there are six economies (Indonesia, Singapore, Thailand, South Korea, the Philippines, and Taiwan) that would be required to change their policy rules to conform to the US dollar peg regime.

${ }^{20}$ We should note that this counterfactual experiment on East Asia's regime shift is subject to the Lucas critique, according to which the model parameters, including import and export shares, will change after a regime shift and thus the simulation results based on the old model may be invalid. If this critique is taken seriously, a stochastic dynamic general equilibrium (SDGE) model with a representative agent maximizing her lifetime utility would be an alternative to the current model. But it is extremely difficult to construct a multi-country SDGE model that is realistic enough to describe the developing economies and can be applied to policy issues. Our model has the advantage that it is fairly easy to manipulate and produces plausible dynamics, as reported in the previous section.
} 
growth rate of Thai domestic demand (a -2.5 percent decline every quarter for four quarters <periods 1 to $4>$ ) and a 10 percent rise in the Thai risk premium (once in period 1 ) ${ }^{21}$ In Table 3, the top panel is a summary of standard deviations of the output gaps. ${ }^{22}$ In the bottom panel, we put an "o (x)" on a country whose standard deviation of the output gap decreases (increases) more than 5 percent by switching from one policy regime to an alternative. We use the Pareto optimality criterion to judge the desirability of one policy regime against the other. Thus, consider two policy regimes, A and B. Regime A is judged superior to B, if and only if a regime switch from A to B harms no East Asian economies and benefits at least one East Asian economy. Applying this criterion to Table 3, we can conclude that the currency-basket regime is superior to the US dollar peg regimes. A regime shift from the US dollar peg regime to the currency-basket regime harms no East Asian economies and benefits four East Asian economies. We cannot say anything more about the superiority among the three policy regimes, however.

Next, to examine the US demand shock, we assume a 1 percent decline in the growth rate of the US domestic demand (a - -2.25 percent decline every quarter for four quarters <periods 1 to $4>$ ). Table 4 is the summary of the policy-regime evaluation in this case. We find that the currency-basket regime is superior to the US dollar peg regime. We can say nothing more than that, however, about the superiority among the three policy regimes.

These results partly support the claims of currency-basket advocates: The East Asian economy is better off, when switching from the US dollar peg regime to a currency-basket regime. However, the superiority of the currency-basket regime to the current regime is ambiguous. When shifting from the current regime to the currency-basket regime, South Korea is worse off in the face of the Thai demand and risk premium shocks; Thailand and China are worse off in the face of the US demand shock. Put differently, the currency-basket advocates are correct, only when the East Asian economies start from the US dollar peg regime and switch to another policy regimes. They may be wrong, however, when

\footnotetext{
${ }^{21}$ We assume $\kappa_{i}=0$ as an alternative to our standard assumption $\kappa_{i}=1$. As pointed out in Section 3, a rise in the Thai risk premium has no impact on the baht under the latter assumption. Under the former assumption, however, the domestic evaluation of credit toward Thailand is higher than the overseas evaluation, which induces the depreciation of the Thai baht.

${ }^{22}$ A question arises about the appropriate criteria to use in evaluating the preferred policy rule. There is a consensus in developed countries to use both the volatility of their business cycles (the output gap or the volatility of GDP) and inflation rates. There is no consensus, however, on whether the same criteria are applicable for the East Asian economies. Although we use the output gap volatility as a welfare criterion, we do not exclude other options.
} 
considering that the East Asian economies have already switched to the current policy regime.

When we take other shocks in consideration, the desirability of the currency basket regime becomes more ambiguous. For instance, the Japanese risk premium shock creates a fluctuation in the yen/dollar exchange rate and destabilizes economic activity in East Asia. To examine the Japanese risk premium shock, we assume that the Japanese risk premium rises 1 percent (once in period 1) in the model. According to Table 5, we can conclude that the current regime is superior to the US dollar-peg regime. The table, however, says nothing more about the superiority among the three policy regimes. Therefore, if the fluctuation of the yen/dollar exchange rate occurs on a sufficiently large scale, we cannot claim that the currency-basket regime is superior even to the US dollar peg regime.

\section{B. China's Currency Policy Reform and its Anticipated Effects}

China's recent economic achievements have been remarkable. The country's growth rate in the 1990s reached 9.7 percent on average. ${ }^{23}$ In world rankings of nominal GDP, China climbed up from 11th in 1990 to 6th in 2000 (following the US, Japan, Germany, the UK, and France) ${ }^{24}$ This high growth in China was primarily attributed to the government's export-oriented economic policy. China’s exports almost quadrupled during the 1990s, and the country's share of world exports rose to about 5 percent in $2002 .^{25}$

As China has achieved high economic growth, there has been much criticism about its current currency policy. As pointed out above, China has a de facto US dollar peg system. Under this policy, the Chinese yuan does not appreciate, even when the economy grows rapidly. This can pose a threat to its neighbors, who may argue that the Chinese government should shift its currency policy to a free floating system. Under the latter system, the yuan would be expected to appreciate in line with economic growth in China or with an economic downturn in foreign countries.

Below, we first examine what is expected to occur with the yuan appreciation. By doing so, we have an idea about the effects of the yuan's variability on economic activity in the Asian-Pacific region. Second, we simulate the shift in China's currency policy from the current US dollar peg to an inflation-targeting policy and investigate the effects on economic stability in the Asia-Pacific region.

\footnotetext{
23 China, Statistical Yearbook (2001).

24 IMF, World Economic Outlook (WED) Database (October 2001).

25 IMF, Direction of Trade Statistics.
} 
First, we examine the effects of China's yuan appreciation on its Asia-Pacific neighbors. To do so, we simulate the situation in which the yuan appreciates by 10 percent (once in period 1), while keeping its de facto US dollar peg system. As shown in Figure 7, the yuan appreciation increases Chinese imports and its neighbors' exports. However, a 10 percent appreciation of the yuan has only limited impacts on the growth rate outside China. For instance, as shown in the figure, real output in Thailand increases only by 0.35 percent after two years, which is much smaller than its growth rate of 5.4 percent in 2002. The effects on Japan and the US are even smaller: Japanese real output increases less than 0.064 percent and US real output rises only 0.019 percent after two years. ${ }^{26}$ The effects on other countries are available from the authors on request.

In spite of the quantitatively limited impacts on the economic activity in the Asia-Pacific region, China's currency policy reform is nonetheless an important issue for the world economy. Next, we explore the possible effects of China shifting its currency system from a de facto US dollar peg to a free floating system. We assume that China adopts an inflation-targeting policy after it abandons the US dollar peg and also that it is still concerned with stabilization of the yuan against the US dollar. We use equation (20) as an inflation targeting formula and assume that China uses the averaged rules of South Korea, Thailand, and the Philippines. ${ }^{27}$ Since the evaluation of China's currency policy reform depends on the nature of shocks, we consider three types of shocks: (1) a negative demand shock originating in China; (2) a negative demand shock originating in the US; and (3) a negative demand shock originating in Japan.

We start with the case of a 1 percent decline in the growth rate of the Chinese domestic demand (a -0.25 percent decline every quarter for four quarters <periods 1 to $4>$ ). A shift from the US dollar peg to the free floating system does not always hurt the Chinese economy. Under the free floating system, the depressing shocks on the Chinese economy may be weakened, owing to a reduction in its imports caused by the depreciation of the yuan. Table 6 shows the standard deviations of the output gaps in the eleven economies. We put an "o (x)" on a country whose standard deviation of the output gap decreases (increases) more than 5 percent by the reform. Table 6(a) shows that China enjoys a substantial gain from its currency reform in the face of its own recession. In contrast, all the foreign

\footnotetext{
${ }^{26}$ Note that we do not take into account the possibility that the yuan appreciation shifts China's exports to its neighbors. Therefore, our estimated effects of China's currency policy reform may be subject to underestimation. ${ }^{27}$ The parameter on $\Delta \ln C P I$ is 3.6 and that on $\Delta \ln E$ is 0.35 .
} 
countries will be faced with greater economic instability due to a reduction in exports caused by the yuan depreciation.

Next, we consider the case of a 1 percent decline in US domestic demand growth rate (a -0.25 percent decline every quarter for four quarters $<$ periods 1 to $4>$ ). Table 6(b) shows that under the free floating system, the yuan appreciation in the face of the US recession hurts the Chinese economy. In contrast, its neighbors avoid substantial reductions in their exports, owing to the yuan appreciation. As for the US, it gains nothing by China's currency reform. It is also worth noting that the Hong Kong economy suffers from a large decline in real output along with China’s economic decline.

Finally, we discuss the case in which the growth rate of Japanese domestic demand declines by 1 percent per annum (a -0.25 percent decline every quarter for four quarters <periods 1 to $4>$ ). While the Japanese yen depreciates, it is not certain whether the yuan appreciates against the US dollar. According to the simulation results, the yuan appreciates against the dollar only slightly. China's currency reform thus has limited impacts on the Asia-Pacific region in the case of the Japanese recession. Looking at Table 6(c), we can see that there are no substantial changes observed in the stability of the economies outside China.

To sum up, China's currency policy reform benefits China itself, but harms its neighbors in the face of the Chinese economic recession. In the case of the US recession, China's currency reform harms the Chinese economy, but benefits most of its neighbors. For a recession originating in Japan, we find no substantial effects on the Asia-Pacific economies. If the possibility of the US recession is taken most seriously, the Chinese government may wish to keep the current de facto US dollar peg, while its neighbors maintain that China should switch to a free floating system.

\section{The Non-Negativity Constraint on Nominal Interest Rates}

Here we discuss the spillover effects of the non-negativity constraint on the Japanese nominal interest rates on the Asia-Pacific region. Since the zero interest rate policy (1999) and the quantitative easing policy (2001) were implemented, the uncollateralized overnight call rate has remained at the zero percent level in Japan. The negative effects of the non-negativity constraint on the Japanese economy have been discussed intensively, but the effects on foreign countries have attracted less attention. Clearly, depressing shocks originating in Japan will spill over to the Asia-Pacific region. Eventually, 
the effects on the East Asian economies will feed back to the Japanese economy through the production network in which the Japanese economy is involved.

We examine the various effects of the non-negativity constraint by simulation analysis, using our Asian Economy Model. For simplicity, we assume the non-negativity constraint only on the Japanese nominal interest rates. Clearly, when other countries confront a non-negativity constraint, the overall economic dynamics in the Asia-Pacific region will be different from those presented below. Nonetheless, we maintain the simplified assumption so as to derive clear implications of the non-negativity constraint on the East Asian economies as well as on the Japanese economy.

We simulate a scenario in which the growth rate of Japanese domestic demand decreases. Large and persistent negative shocks are required to create the situation in which the nominal short-term interest rate hits a non-negativity constraint. To do so, we assume that negative demand shocks, $\varepsilon_{D}$, on the Japanese growth rate follow a long-lasting autoregressive process with large innovations, $\eta_{D}$ :

$$
\varepsilon_{D t}=\rho_{D} \varepsilon_{D t-1}+\eta_{D t} .
$$

For concreteness, we assume $\rho_{D}=0.8$ and $\eta_{D}=0.025$ for four consecutive quarters (periods 1 to 4 ; 10 percent shock per annum in total).

The effects on the Japanese economy are shown in Figure 8, where dynamics are generated with and without the non-negativity constraint on the Japanese nominal interest rates. Note that the short-term nominal interest rate is shown as a deviation from its steady state level, which is 4.2 percent in the current case (the sample mean of the uncollateralized overnight call rate in Japan). Thus, the non-negativity constraint is given by the dashed horizontal line at a -4.2 percent level. In the current scenario, the short-term interest rate hits the zero-bound for about 3 years from the 4th quarter to the 15th quarter. The largest discrepancy from the non-negativity constraint is 5.6 percent in the 9th quarter. As pointed out in Section 4, the economic slump and the resulting deflation are more severe than those obtained if there were no non-negativity constraint.

The non-negativity constraint on the Japanese nominal interest rates has two opposing effects on East Asian economies. First, the non-negativity constraint restricts a further decline in the Japanese short-term interest rate. Therefore the yen does not depreciate much. In the Thai case, for example, the real effective exchange rate does not appreciate significantly. In Figure 9, which depicts impulse responses of the Thai economy, we find that the non-negativity constraint on the Japanese interest rate 
makes no difference in the output gap during the first six quarters, but creates a larger negative output gap from the 7th to 15th quarters than that obtained without the non-negativity constraint. The depression in the Japanese economy does slow its imports and spills over to the East Asian economies. We can see in the figure that the second effect overweighs the first one during periods 6 to 13 .

\section{CONCLUSION}

In this paper, we present a macro-econometric model that describes the Asia-Pacific economy and apply the model to discuss current issues of policy coordination among the East Asian economies. A remarkable achievement of the East Asian economies is the international production network that has developed across the region. This network has not only fostered rapid economic growth, but it has also facilitated the transmission of economic shocks and policy changes throughout the region.

The open-economy tri-lemma suggests that the three policy goals-independent monetary policy, a stable exchange rate, and free capital mobility — cannot be pursued simultaneously. In the late 1980s and the early 1990s, some East Asian economies encouraged capital inflows to finance growth and achieved it by pegging their currencies to the US dollar. As a result, governments lost control over economic activity and were eventually subjected to massive capital flight. The 1997 Asian Currency Crisis was therefore a consequence of wrong policies pursued by some growth-oriented East Asian economies combined with the interdependent international production network developed in East Asia.

We have carried out a set of policy combinations actually observed in East Asia and incorporated changes into the macro-econometric model. We create various policy regimes by replacing the incorporated policy rules with alternatives and evaluate their performance in economic stabilization. One question is whether currency-basket pegs are recommendable to the East Asian economies. Our simulation analysis suggests that currency-basket pegs seem superior to a US dollar peg in the face of own-country economic crisis as well as with a US recession. Taking into consideration other types of shocks, however, the superiority of currency-basket pegs becomes ambiguous. Moreover, after some East Asian economies carry out policy reforms, it is not clear that all the economies will be better off by switching further to currency-basket pegs.

Our model can also be used to provide insights into a wide variety of current policy debates, including China's currency policy reform. Our simulation analysis shows that a 10 percent 
depreciation of the yuan is too small to have substantial impacts on economic activity outside China. Second, China and other East Asian economies have conflicting interests towards China's currency reform from the current de facto US dollar peg to a free floating system: The reform benefits China and harms most of the Asia-Pacific economies in the face of China's recession. On the other hand, the reform benefits most of the Asia-Pacific economies and harms China in the face of a US recession. These results suggest that the US should be involved in the negotiation process in order for China's currency reform to be successfully achieved.

The econometric model introduced in this paper has wide applicability beyond the policy coordination problem analyzed above. As an example, we have also analyzed the external economy effects of the non-negativity constraint on the Japanese interest rates on the East Asian economies. 


\section{REFERENCES}

Bayoumi, T. (1996), 'International Trade and Real Exchange Rates,' in Exchange Rate Movements and Their Impact on Trade and Investment in the APEC Region, International Monetary Fund, Washington, D.C.,.

Fischer, S. (2001), 'Exchange Rate Regimes: Is the Bipolar View Correct?' a speech delivered at the meeting of the American Economic Association, New Orleans, January 6.

Frankel, J. A., and S-J. Wei (1994), 'Yen Bloc or Dollar Bloc: Exchange Rate Policies of the East Asian Economies,' in T. Ito and A. O. Krueger (eds.), Macroeconomic Linkage (Chicago University of Chicago Press).

Fukuda, S., and C. Ji (2001), ‘Tsuka kiki go no higashi asia no tsuka seido (East Asia’s Currency System after the Asian Currency Crisis),' Monetary and Economic Studies, Institute for Monetary and Economic Studies, Bank of Japan, 20, 4, (in Japanese).

Goldstein, M., G. L. Kaminsky, and C. M. Reinhart (2000), Assessing Financial Vulnerability, Institute for International Economics, Washington, DC.

Isogai, T., H. Morishita, and R. Rüfer (2002), 'Higashi Asia no boueki wo meguru bunseki - hikaku yui kouzou no henka, ikinaigai boueki flow no sougo izon kankei (An Analysis of East Asian Trade structural changes in comparative advantage and interaction of intra- and inter-regional trade in East Asia),' Bank of Japan International Department Working Paper Series, No. 02-J-1, (in Japanese).

Kamada, K., K. Nakayama, and I. Takagawa (2002), 'Deepening Interdependence in the Asia-Pacific Region: An Empirical Study Using a Macro-Econometric Model,' Bank of Japan Research and Statistics Department Working Paper Series, No. 02-9.

Kamada, K., Y. Oenoki, and K. Watanabe (1998), ‘A Local Model of Asian Economies,’ Bank of Japan Research and Statistics Department Working Paper Series, No. 98-5.

Kawai, M. (2002), 'Exchange Rate Arrangements in East Asia: Lessons from the 1997-98 Currency Crisis,' Institute for Monetary and Economic Studies Discussion Paper Series, No. 2002-E-17.

Kwan, C.H. (1995), En ken no keizai gaku (Economics in the yen area), Nihon keizai shinbunsha (in Japanese). 
Figure 1

Output and Trade in the Asia-Pacific Region

a. Nominal GDP and Trade

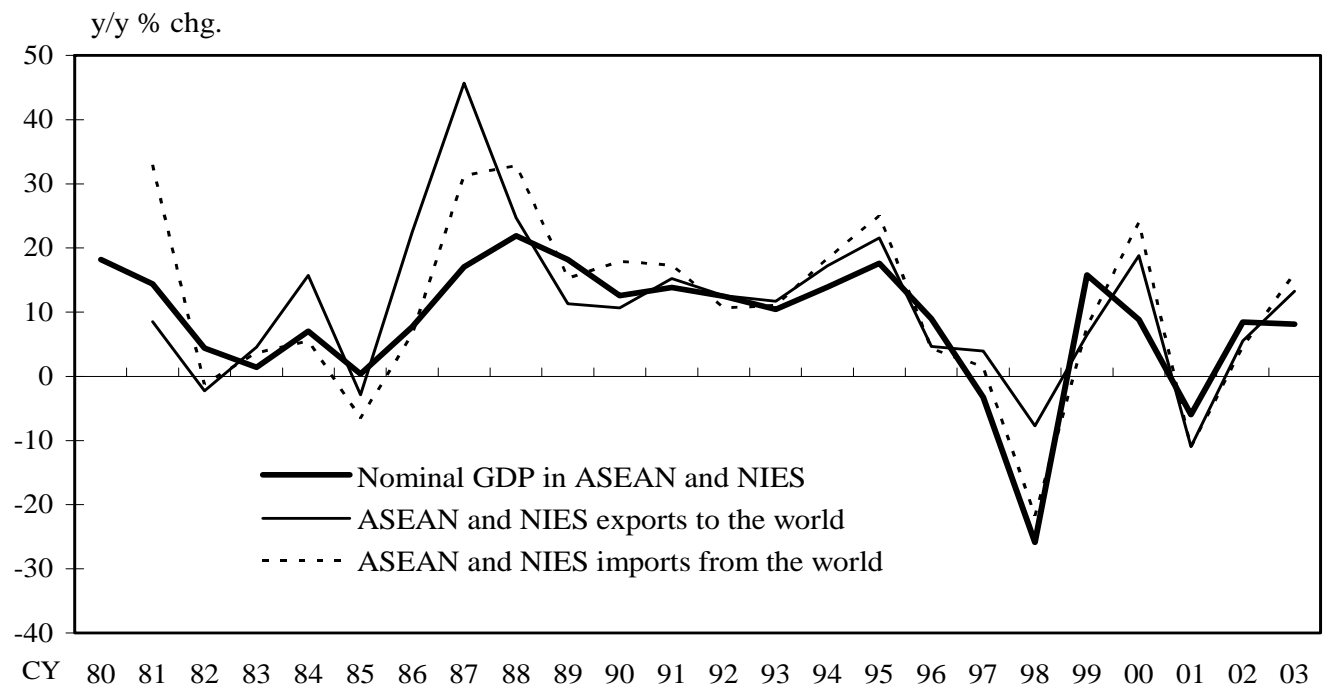

b. Intra-regional Trade Ratio in East Asia

(\%)

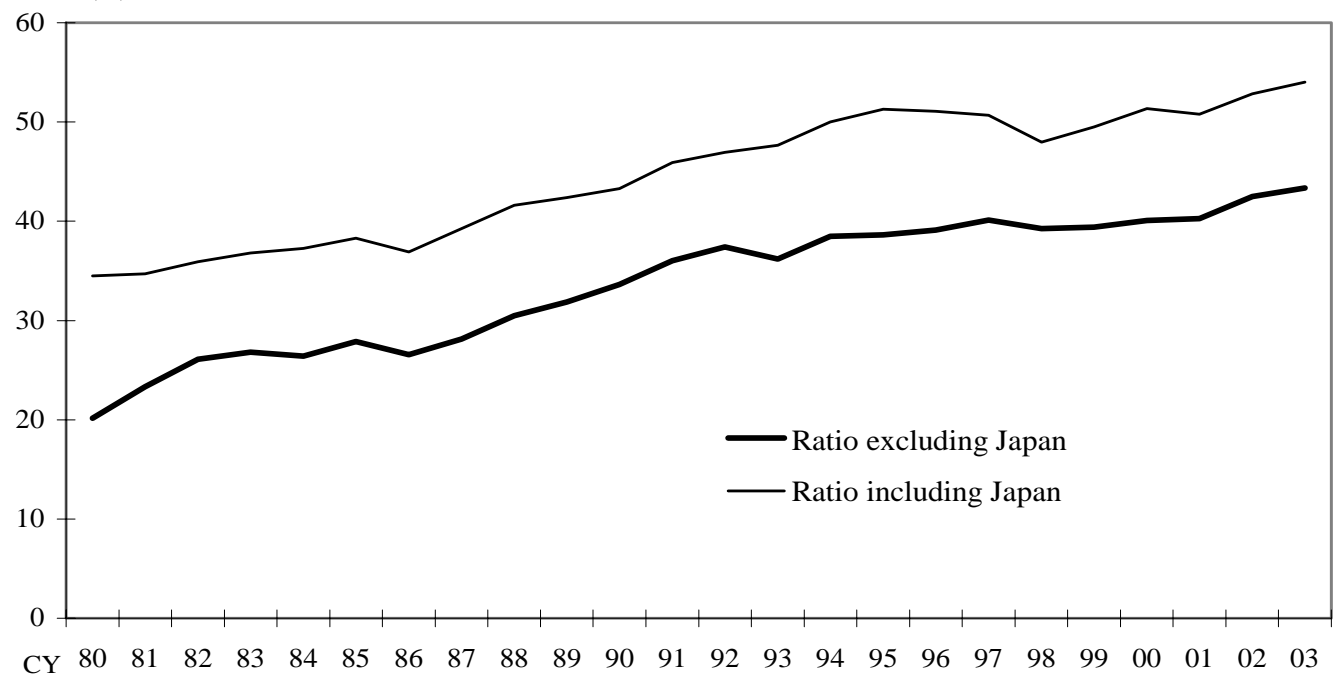

Note: “Nominal GDP,” “Exports,” and “Imports” are year-to-year percent changes of aggregated nominal GDP, exports, and imports denominated in dollars, respectively.

Sources: International Monetary Fund, “International Financial Statistics,” "Direction of Trade Statistics.” CEIC database. 
Figure 2

Impulse Response: (i) A 1 percent decline in the growth rate of the Japanese domestic demand $<$ Effects on Japan $>$
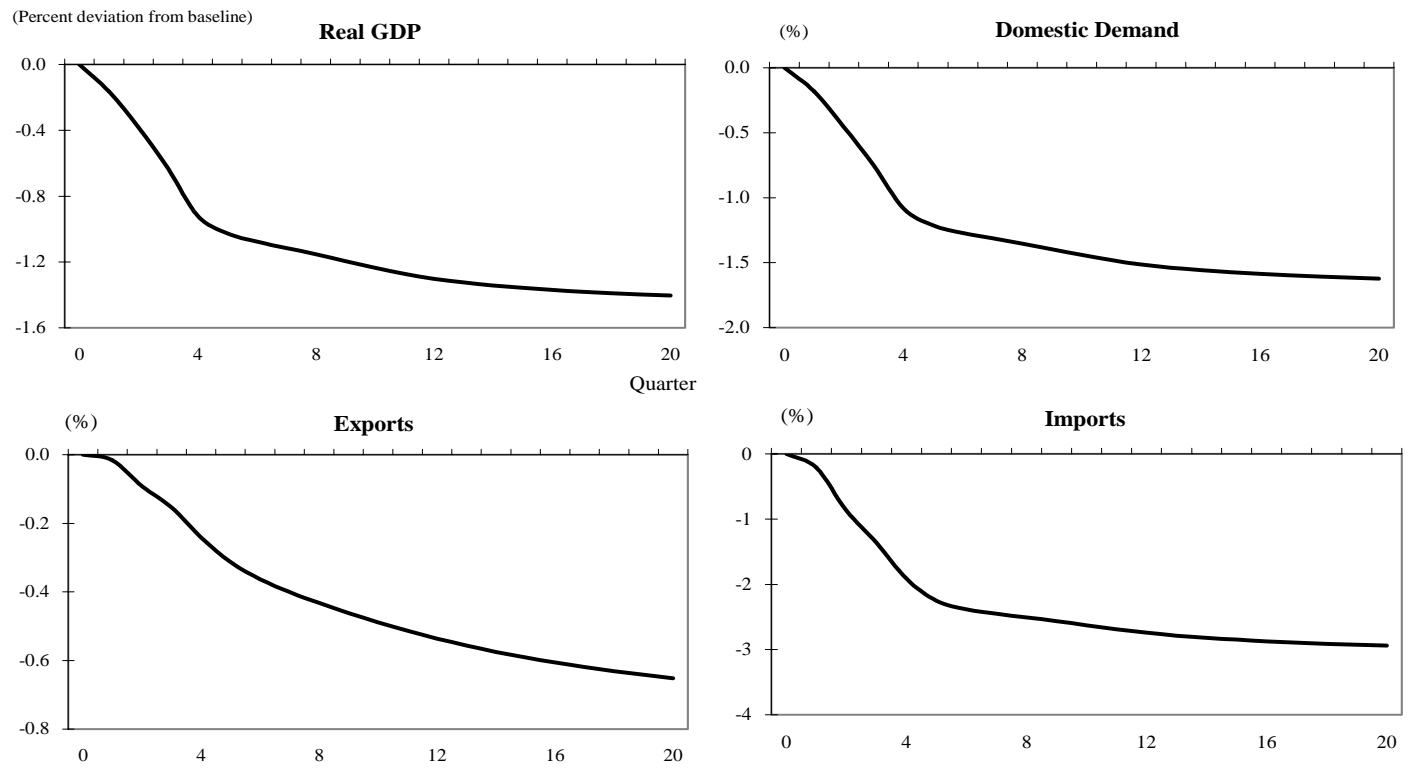

(\%) Nominal Exchange Rate (against US dollar)
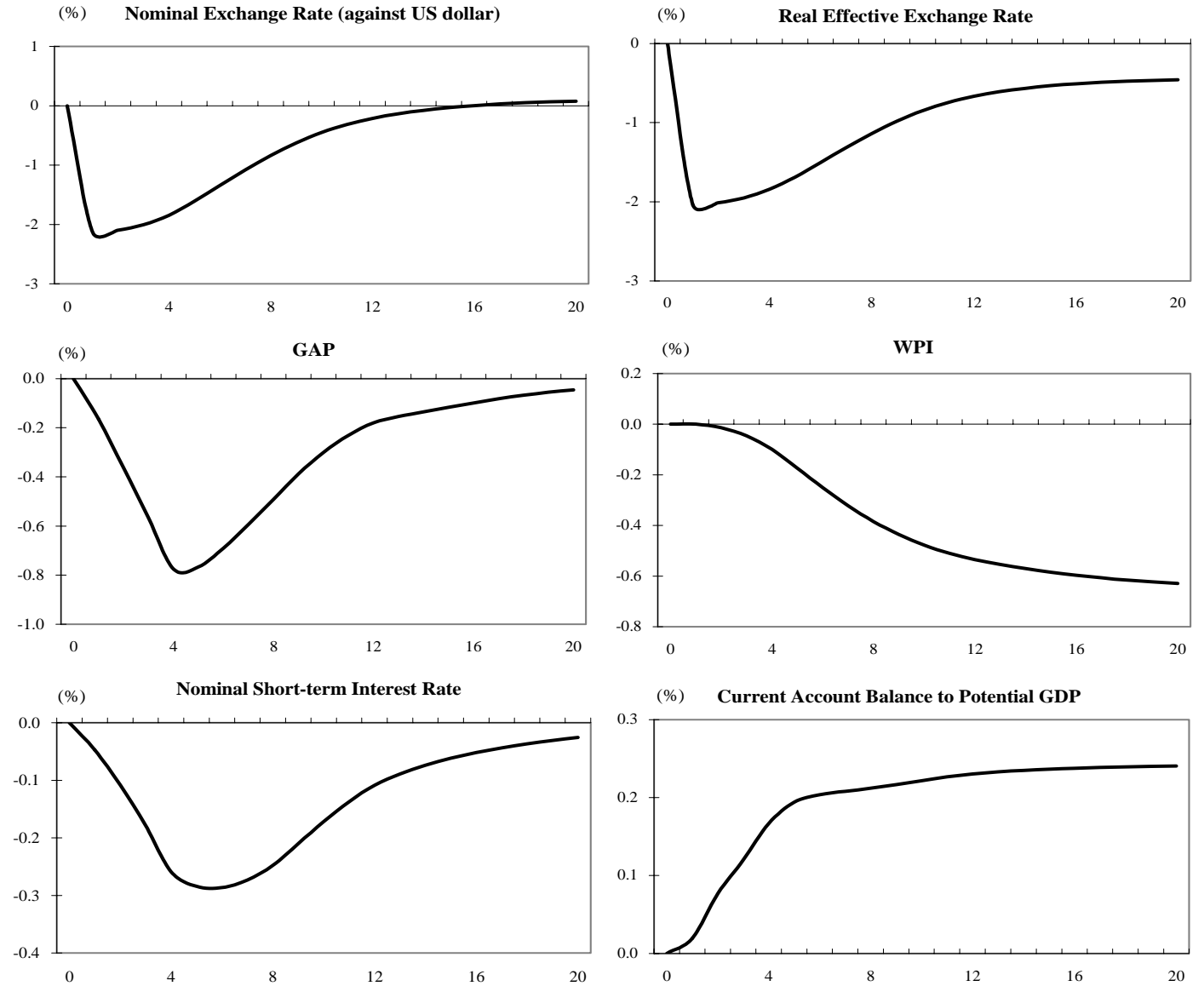
Figure 3

Impulse Response: (i) A 1 percent decline in the growth rate of the Japanese domestic demand $<$ Effects on Thailand $>$
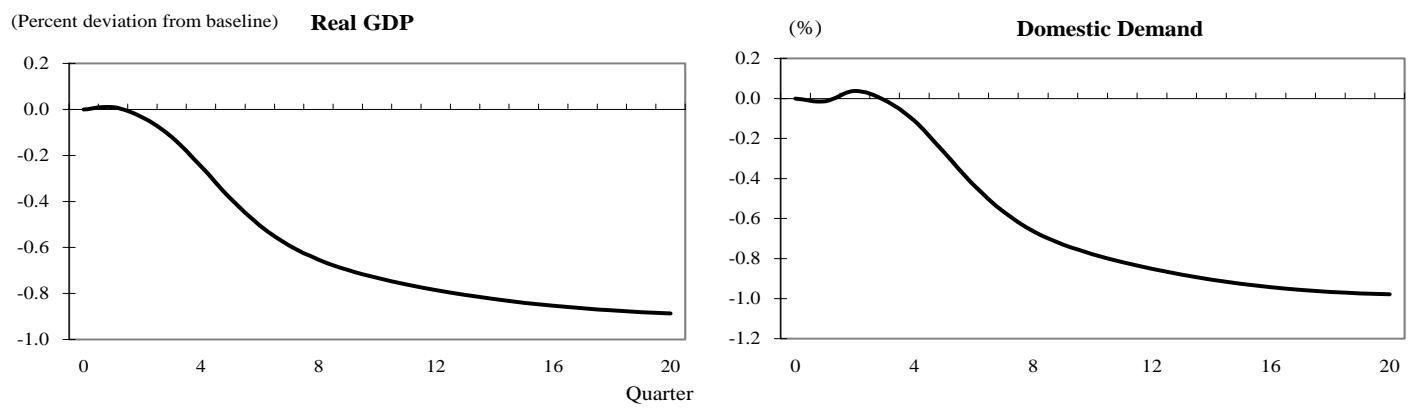

(\%) Exports
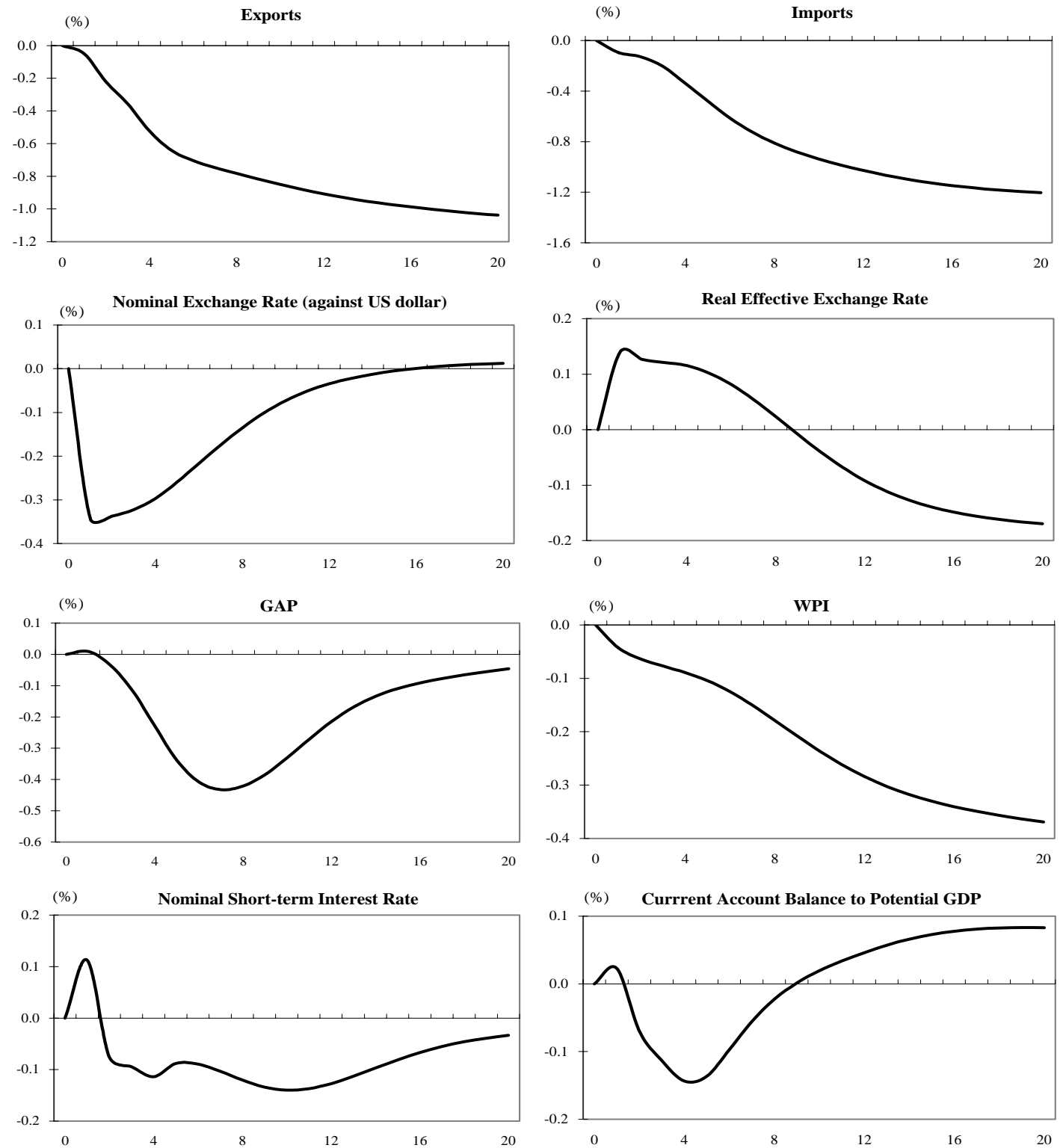
Figure 4

Impulse Response: (ii) A 1 percent decline in the growth rate of the US domestic demand $<$ Effects on Japan>
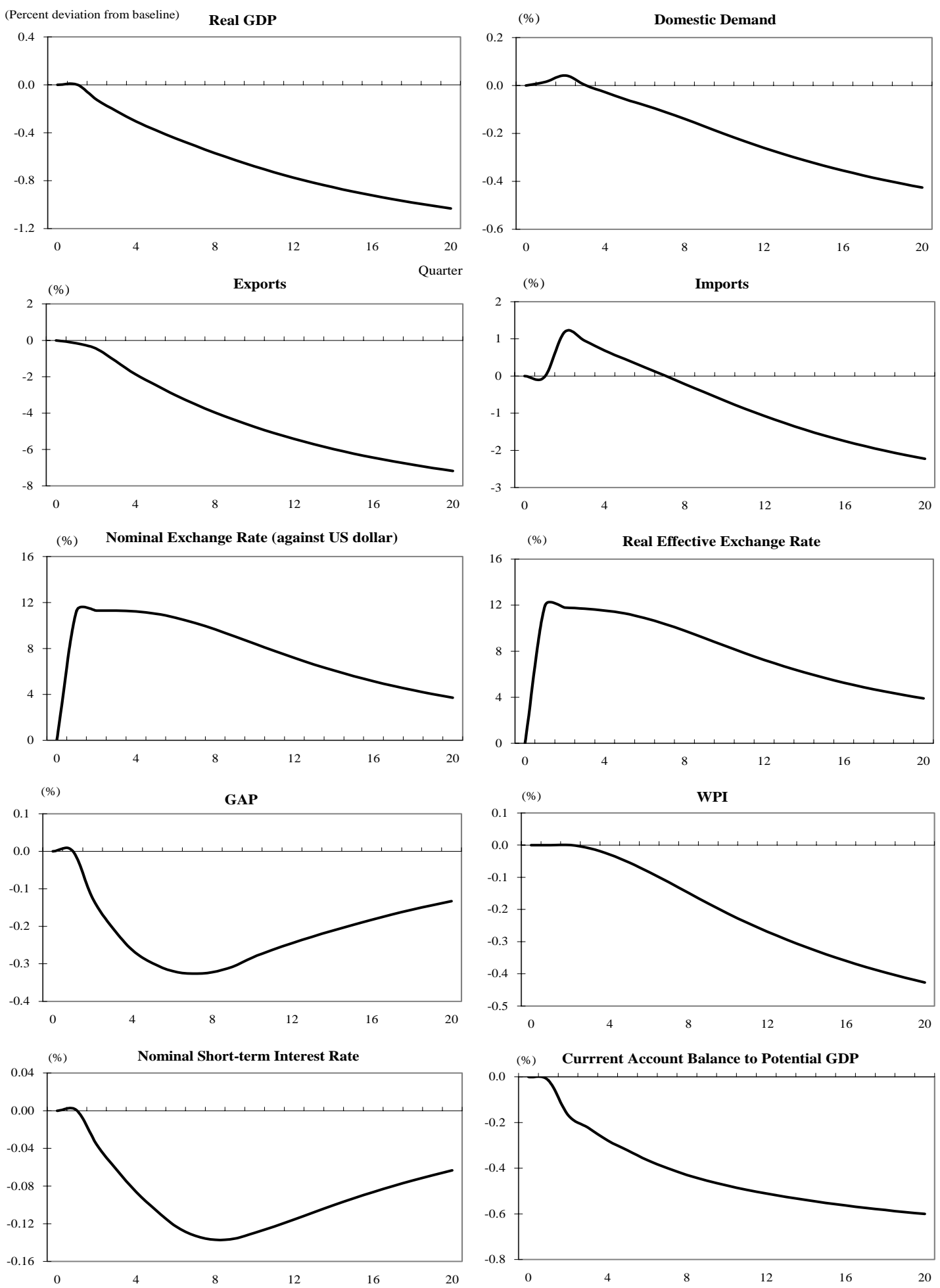
Figure 5

Impulse Response: (iii) A 1 percent decline in the growth rate of the East Asian domestic demand $<$ Effects on Japan $>$
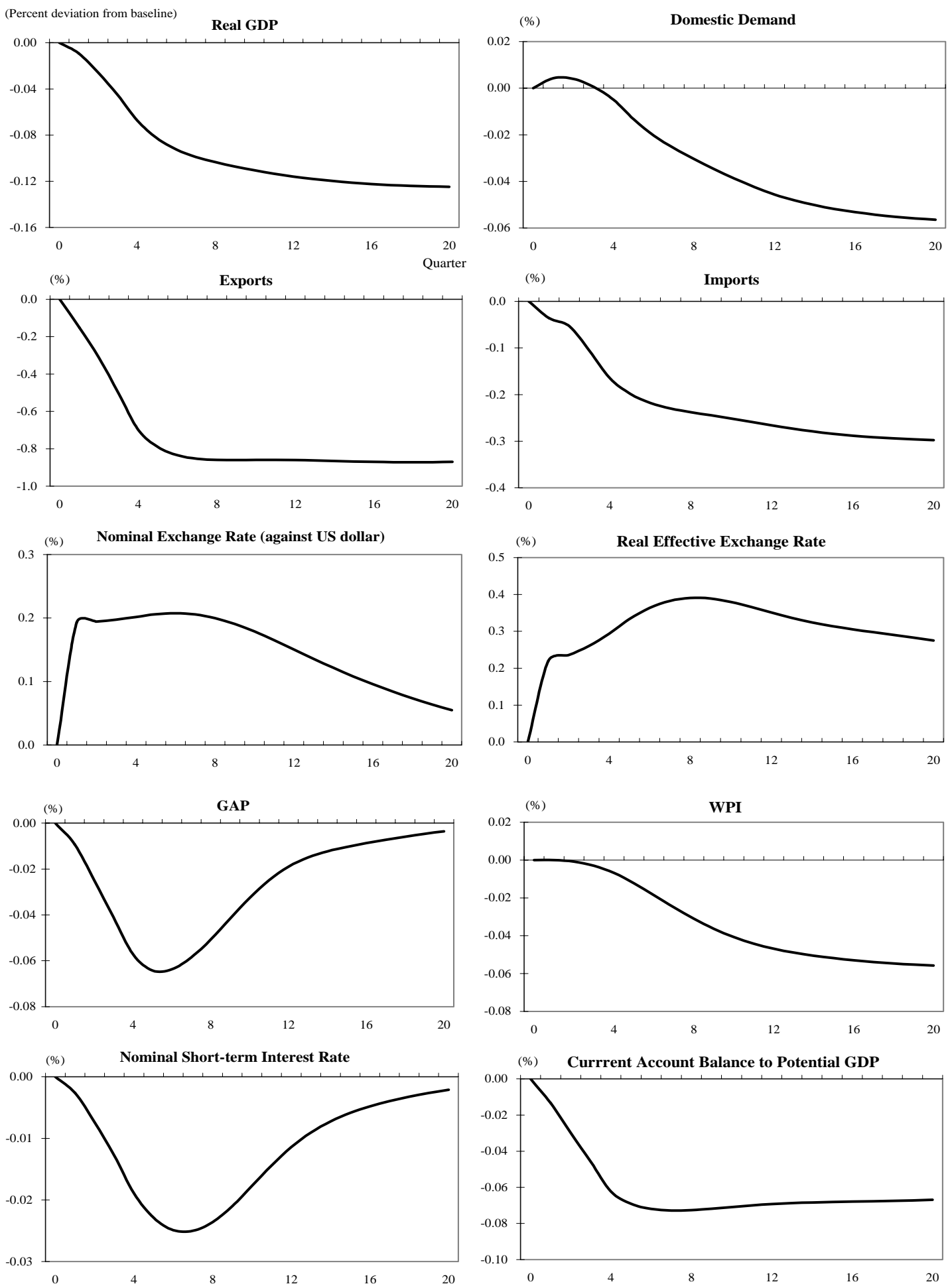
Impulse Response: (iv) A 1 percent decline in the growth rate of the Asia-Pacific domestic demand $<$ Effects on Japan>
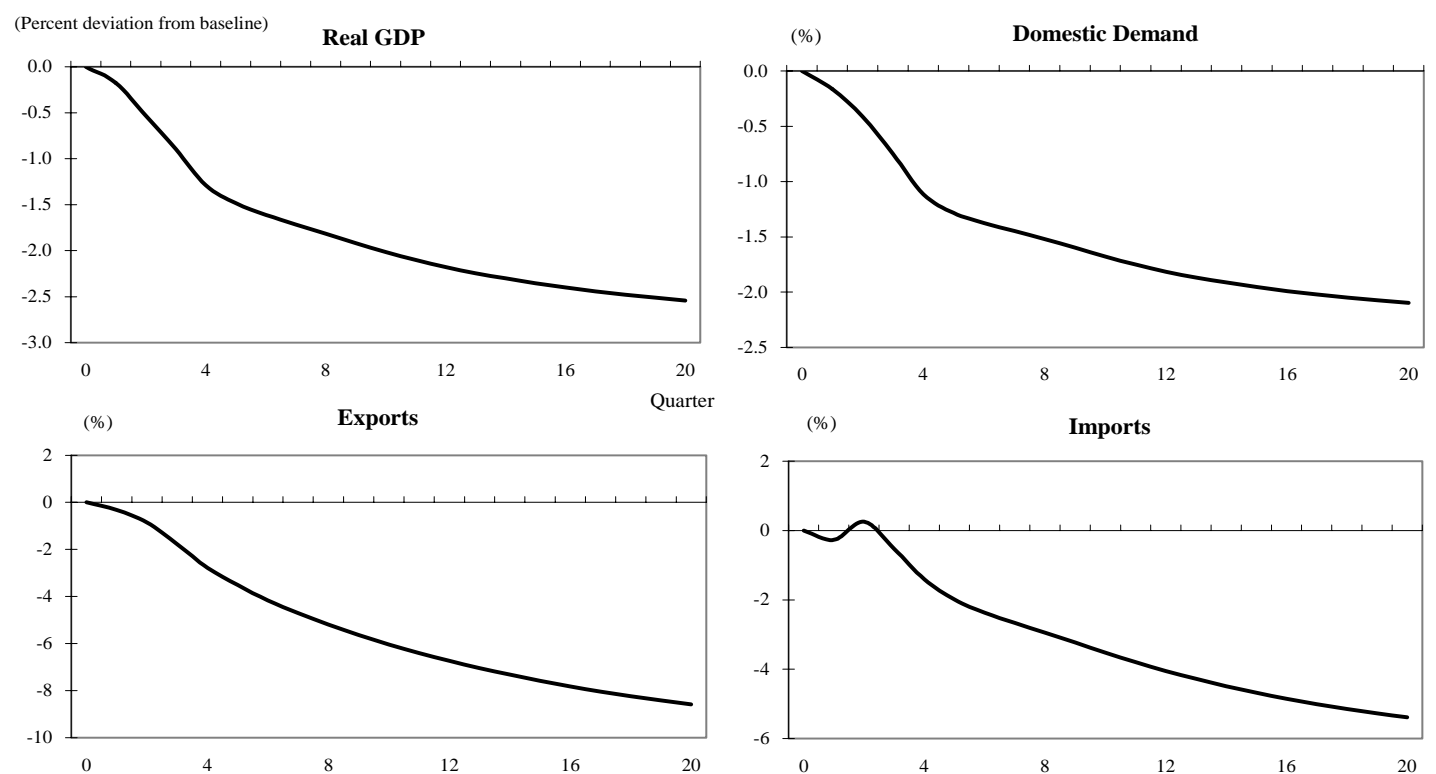

(\%) Imports
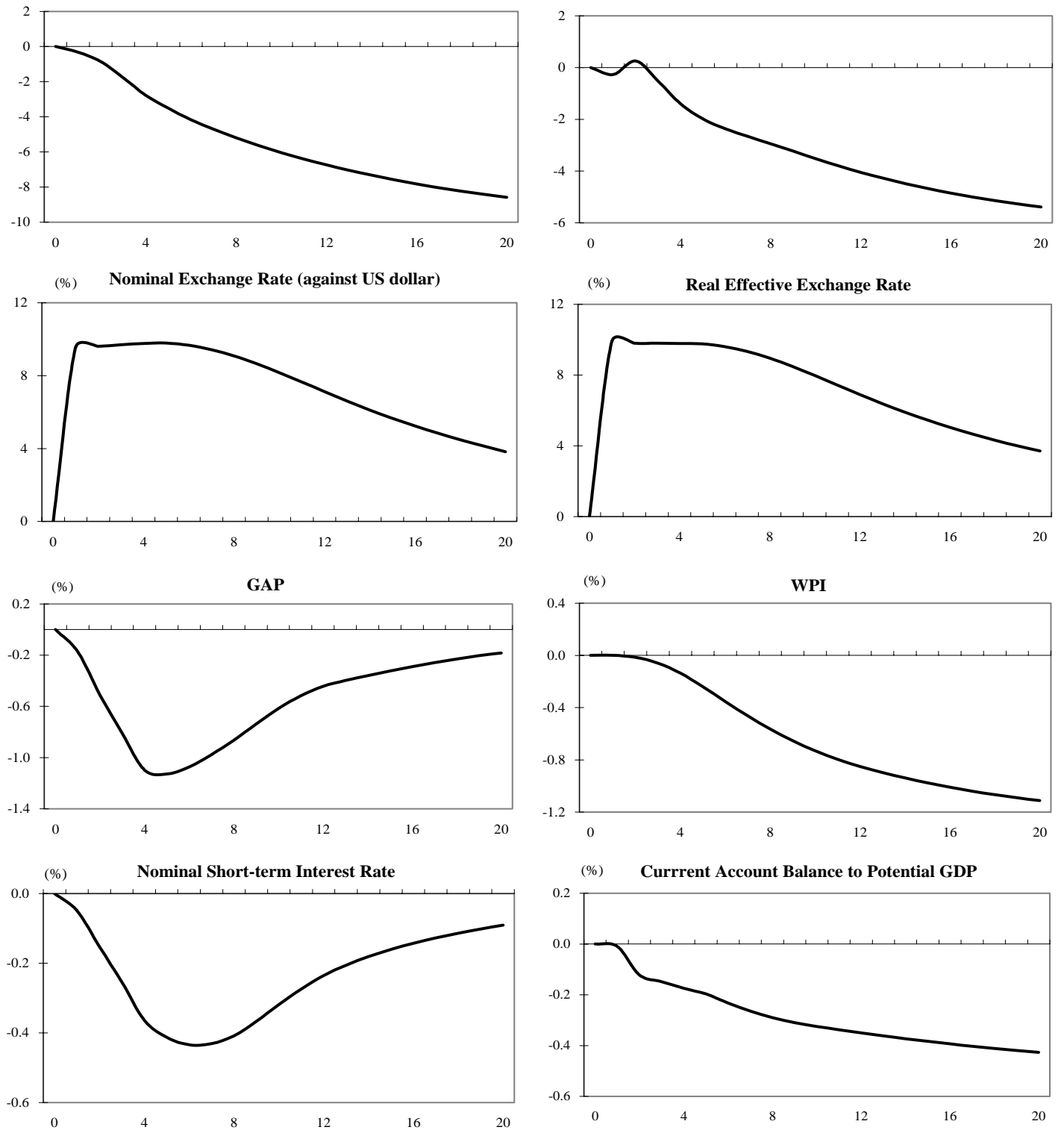
Figure 7

Effects of a 10 Percent Yuan Appreciation
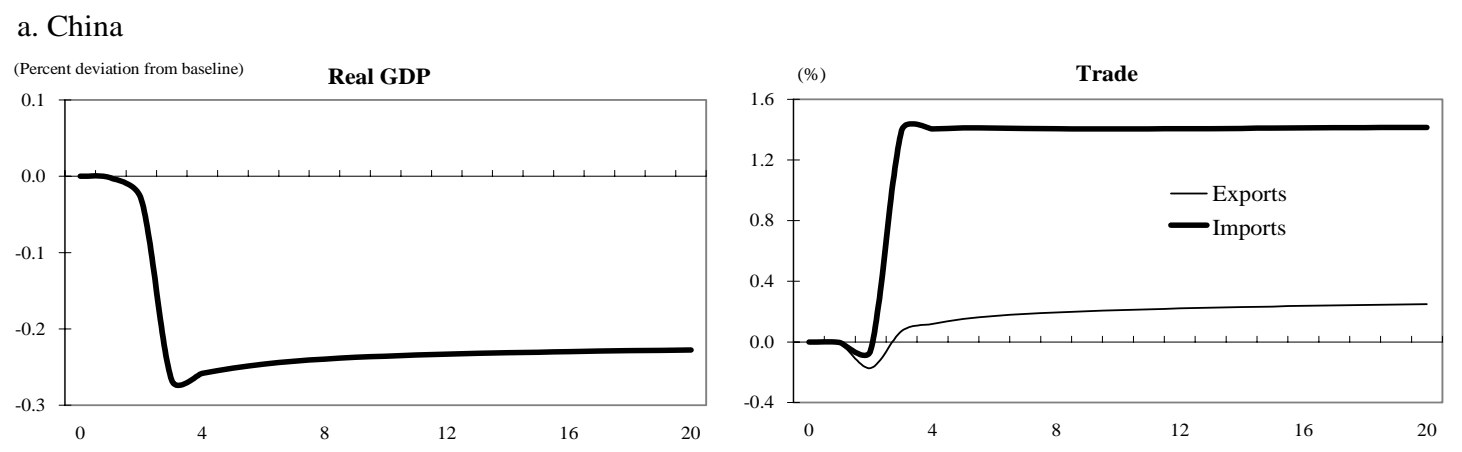

b. Thailand
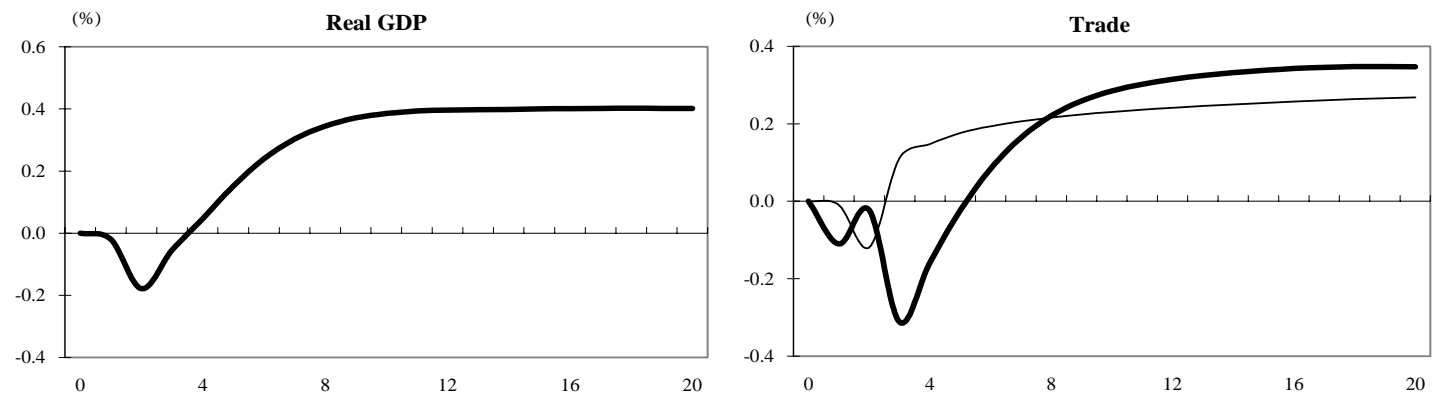

\section{c. Japan}
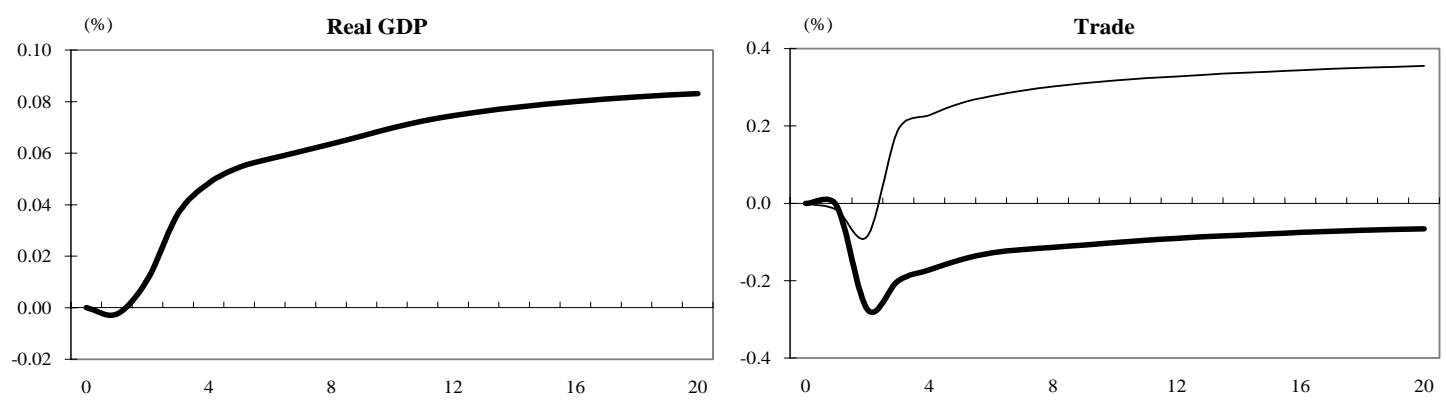

d. US
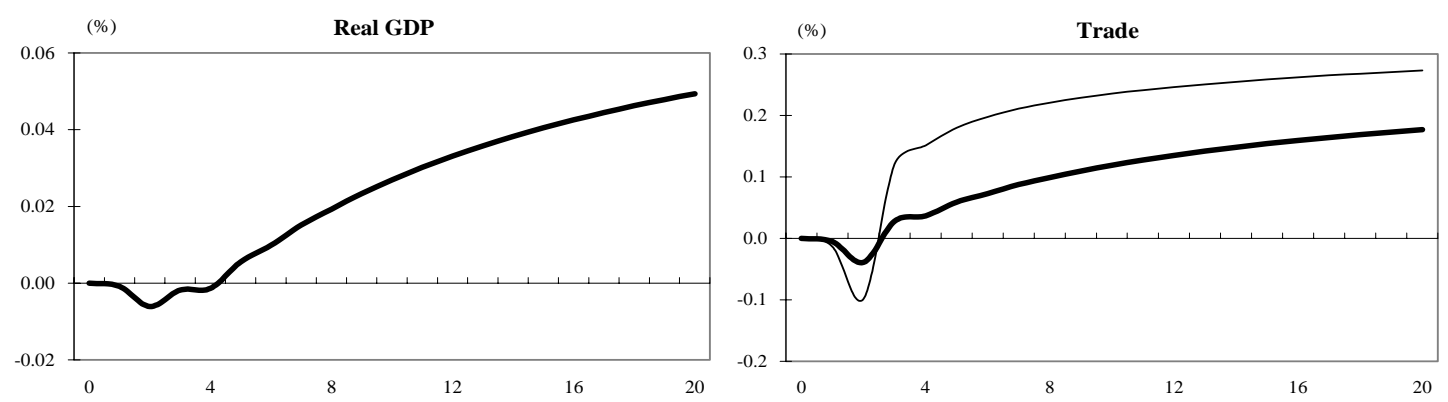

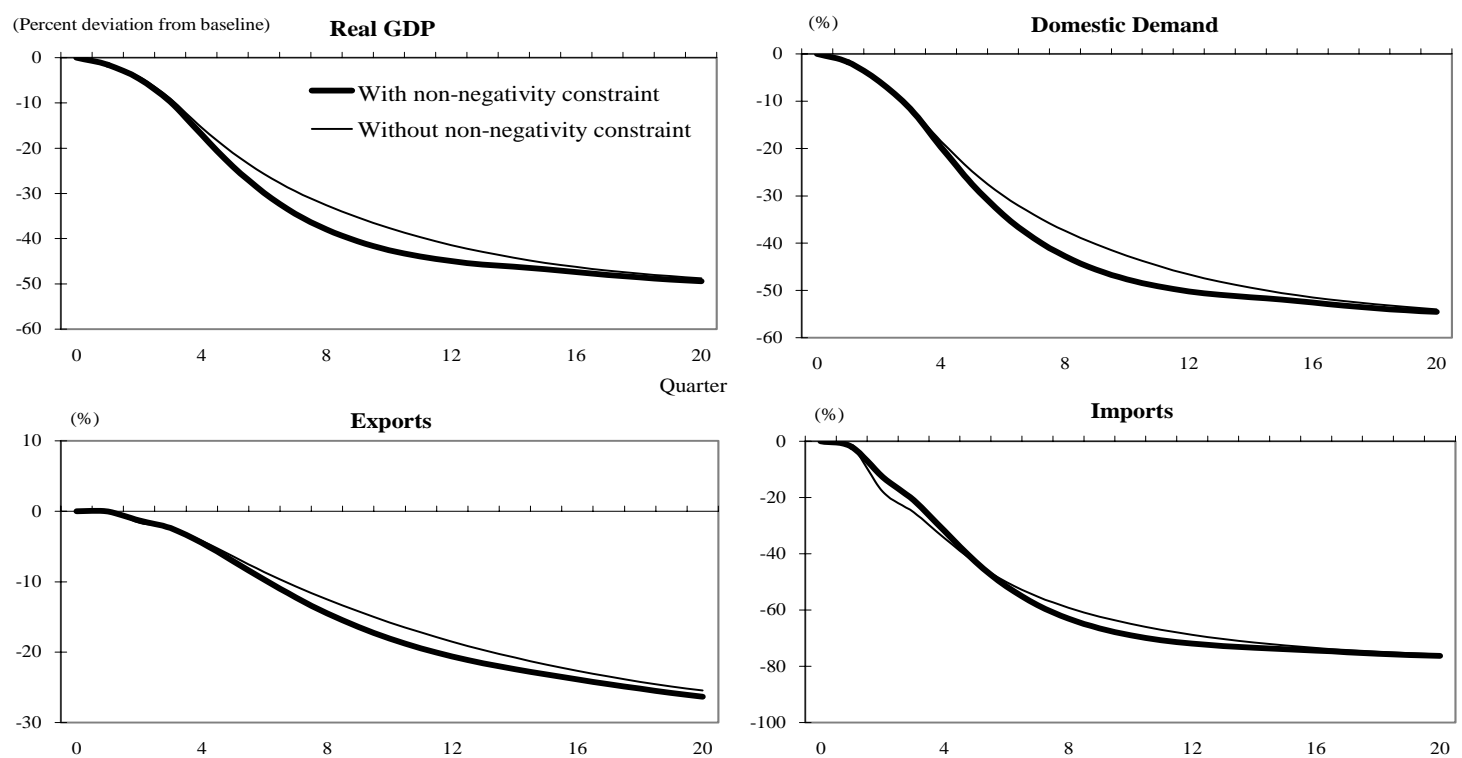

(\%) Nominal Exchange Rate (against US dollar)

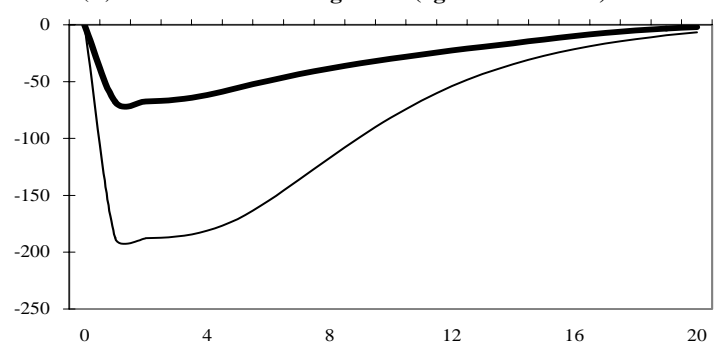

(\%) Real Effective Exchange Rate

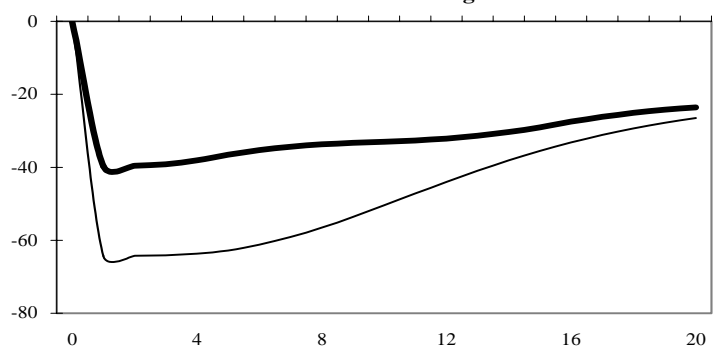

(\%) GAP
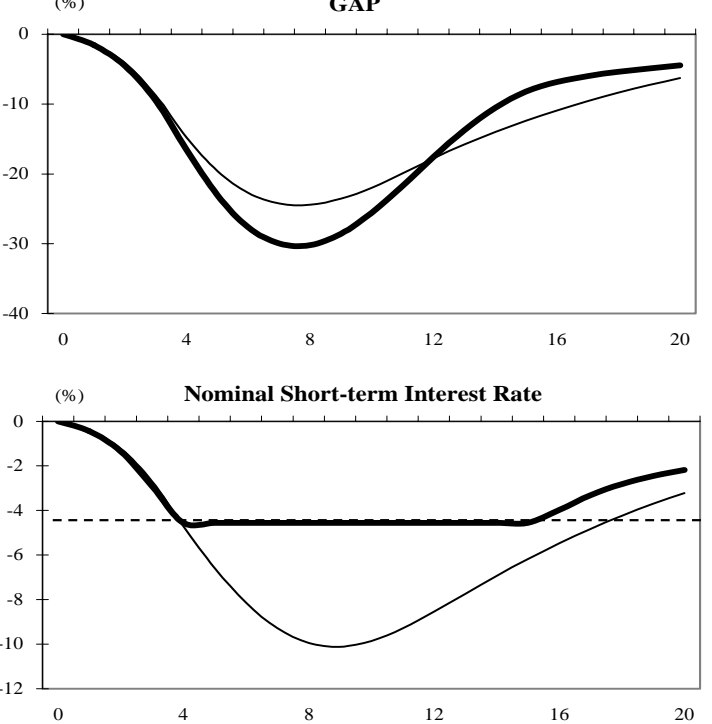
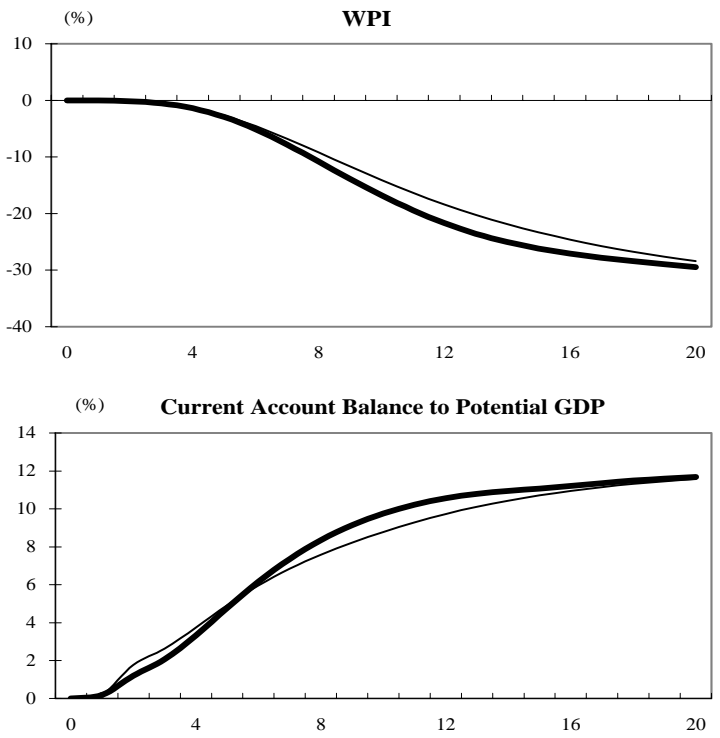

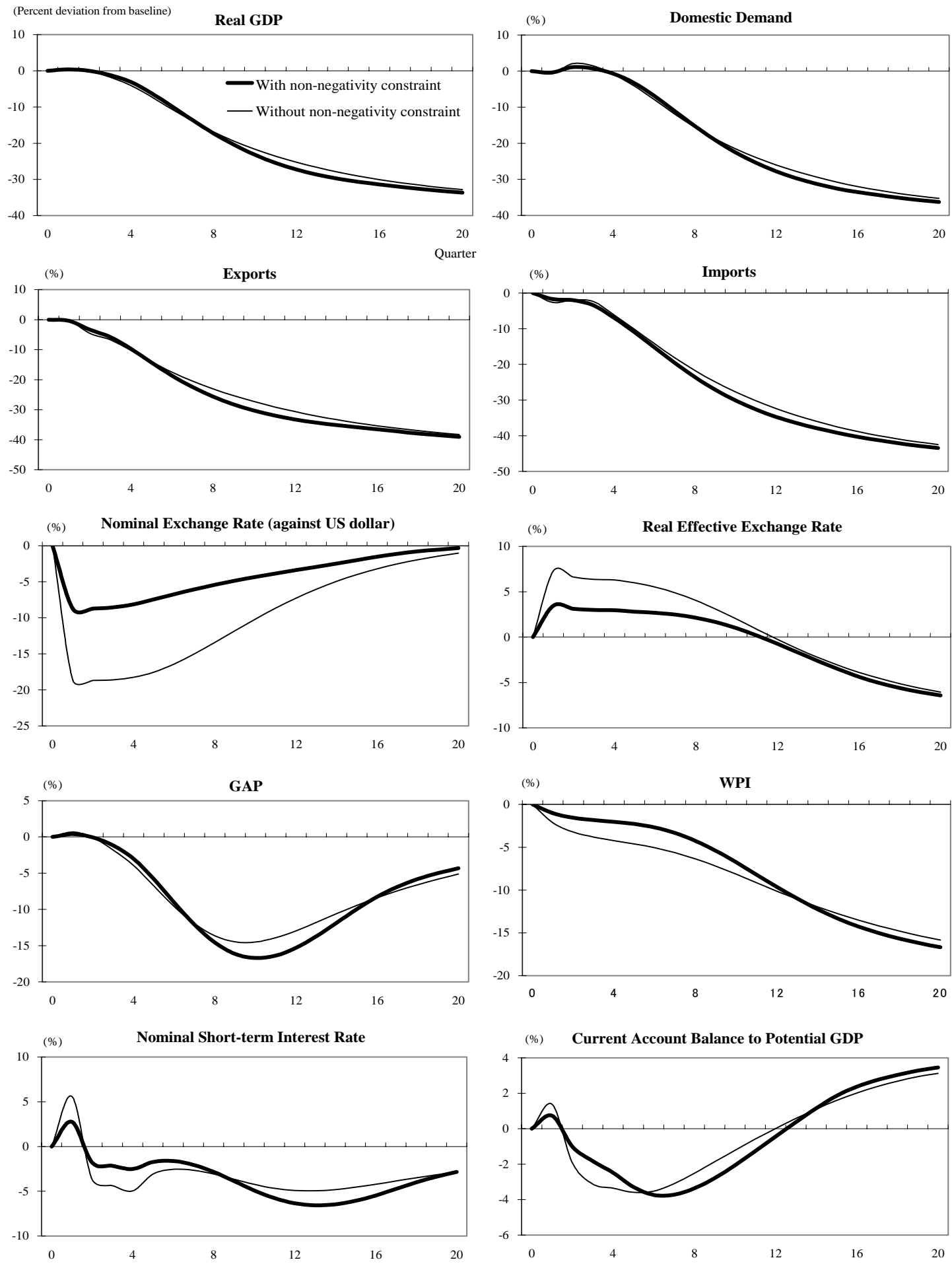
Table 1

Monetary and Exchange Rate Policies Both Before and After Asian Currency Crisis

\begin{tabular}{|c|c|c|}
\hline & Before Asian Currency Crisis & After Asian Currency Crisis \\
\hline Japan (yen) & \multicolumn{2}{|c|}{ Taylor Rule / Independently Floating (since February 1973) } \\
\hline United States (dollar) & \multicolumn{2}{|c|}{ Taylor Rule / Independently Floating } \\
\hline Indonesia (rupiah) & Managed Floating (since 1978) & $\begin{array}{l}\text { Managed Floating (since 2001) / } \\
\text { Preparing for Inflation Targeting }\end{array}$ \\
\hline Singapore (Singapore dollar) & \multicolumn{2}{|c|}{ Managed Floating <Currency Basket $>$ (since 1981) } \\
\hline Thailand (baht) & $\begin{array}{l}\text { Managed Floating <Currency Basket> } \\
\text { (since November 1984) }\end{array}$ & $\begin{array}{l}\text { Inflation Tageting (since May 2000) / } \\
\text { Managed Floating (since July 1997) }\end{array}$ \\
\hline The Philippines (peso) & $\begin{array}{c}\text { Independently Floating } \\
<\text { de facto Peg against the US dollar }> \\
\text { (since December 1994) }\end{array}$ & $\begin{array}{l}\text { Inflation Tageting (since 2002) / } \\
\text { Independently Floating (since March 1998) }\end{array}$ \\
\hline Malaysia (ringgit) & Managed Floating (since 1973) & $\begin{array}{l}\text { Fixed Peg Arrangements } \\
\text { (since September 1998) }\end{array}$ \\
\hline South Korea (won) & Managed Floating (since March 1990) & $\begin{array}{l}\text { Inflation Targeting (since September 1998) / } \\
\text { Independently Floating (since December 1997) }\end{array}$ \\
\hline Hong Kong (Hong Kong dollar) & \multicolumn{2}{|c|}{ Currency Board Arrangements (since October 1983) } \\
\hline Taiwan (New Taiwan dollar) & \multicolumn{2}{|c|}{ Managed Floating (since 1979) } \\
\hline China (yuan) & \multicolumn{2}{|c|}{ Fixed Peg Arrangements < de facto Peg against the US dollar $>$ (since 1994) } \\
\hline
\end{tabular}

Note: Taiwan's classification is based on Fischer (2001).

Source: International Monetary Fund, “Annual Report.” 
Table 2

\section{Responses of Real GDP and Exports to Demand Shocks}

(i) A 1 percent decline in the growth rate of the Japanese domestic demand

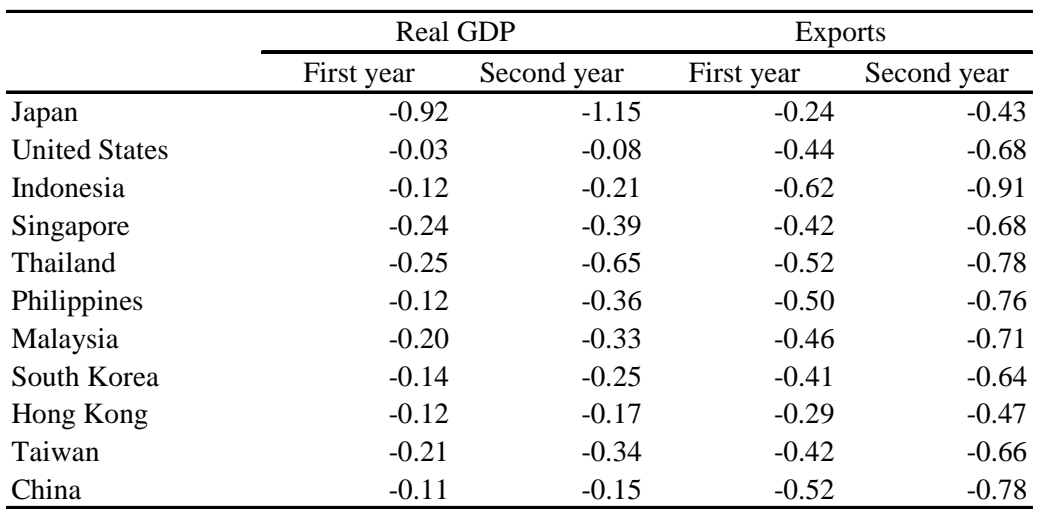

(iii) A 1 percent decline in the growth rate of the East Asian domestic demand excluding Japan

\begin{tabular}{|c|c|c|c|c|}
\hline & \multicolumn{2}{|c|}{ Real GDP } & \multicolumn{2}{|c|}{ Exports } \\
\hline & First year & Second year & First year & Second year \\
\hline$\overline{\text { Japan }}$ & -0.07 & -0.10 & -0.70 & -0.86 \\
\hline United States & -0.04 & -0.09 & -0.58 & -0.73 \\
\hline Indonesia & -1.01 & -1.24 & -0.68 & -0.83 \\
\hline Singapore & -0.57 & -0.66 & -0.85 & -1.00 \\
\hline Thailand & -1.22 & -1.66 & -0.62 & -0.75 \\
\hline Philippines & -0.99 & -0.62 & -0.61 & -0.76 \\
\hline Malaysia & -0.44 & -0.50 & -0.71 & -0.88 \\
\hline South Korea & -0.78 & -0.77 & -0.54 & -0.66 \\
\hline Hong Kong & -0.55 & -0.66 & -0.52 & -0.64 \\
\hline Taiwan & -0.75 & -0.89 & -0.70 & -0.86 \\
\hline China & -1.00 & -1.03 & -0.64 & -0.80 \\
\hline
\end{tabular}

Note: Figures are percent deviations from baseline. (ii) A 1 percent decline in the growth rate of the US domestic demand

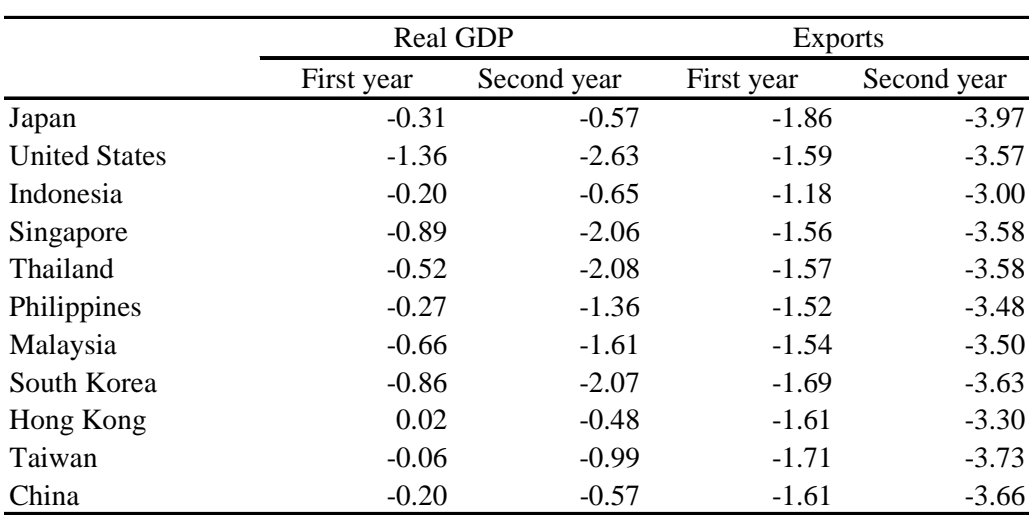

(iv) A 1 percent decline in the growth rate of the Asia-Pacific domestic demand

\begin{tabular}{|c|c|c|c|c|}
\hline & \multicolumn{2}{|c|}{ Real GDP } & \multicolumn{2}{|c|}{ Exports } \\
\hline & First year & Second year & First year & Second year \\
\hline Japan & -1.29 & -1.82 & -2.78 & -5.20 \\
\hline United States & -1.43 & -2.80 & -2.60 & -4.92 \\
\hline Indonesia & -1.33 & -2.09 & -2.47 & -4.68 \\
\hline Singapore & -1.70 & -3.08 & -2.81 & -5.20 \\
\hline Thailand & -1.98 & -4.33 & -2.69 & -5.05 \\
\hline Philippines & -1.39 & -2.33 & -2.61 & -4.94 \\
\hline Malaysia & -1.30 & -2.42 & -2.69 & -5.02 \\
\hline South Korea & -1.77 & -3.07 & -2.62 & -4.88 \\
\hline Hong Kong & -0.65 & -1.30 & -2.40 & -4.37 \\
\hline Taiwan & -1.01 & -2.21 & -2.82 & -5.19 \\
\hline China & -1.30 & -1.74 & -2.74 & -5.17 \\
\hline
\end{tabular}


Table 3

Summary of the Output- Gap Based Evaluations of the Three Policy Regimes

The Demand and Risk-Premium Shocks in Thailand

a. Standard Deviations of Output Gaps

\begin{tabular}{|l|r|r|r|}
\hline & Current regime & US dollar peg regime & $\begin{array}{c}\text { Currecy basket } \\
\text { regime }\end{array}$ \\
\hline Japan & 0.03515 & 0.03510 & 0.03606 \\
US & 0.02728 & 0.02846 & 0.02790 \\
Indonesia & 0.06300 & 0.06499 & 0.06362 \\
Singapore & 0.24970 & 0.25580 & 0.25027 \\
Thailand & 3.42704 & 4.18987 & 3.44070 \\
Philippines & 0.16936 & 0.16646 & 0.16310 \\
Malaysia & 0.18322 & 0.18711 & 0.18437 \\
South Korea & 0.05770 & 0.06513 & 0.06182 \\
Hong Kong & 0.05739 & 0.05091 & 0.04480 \\
Taiwan & 0.11676 & 0.11349 & 0.10747 \\
China & 0.03809 & 0.03762 & 0.03599 \\
\hline
\end{tabular}

b. Significant Changes

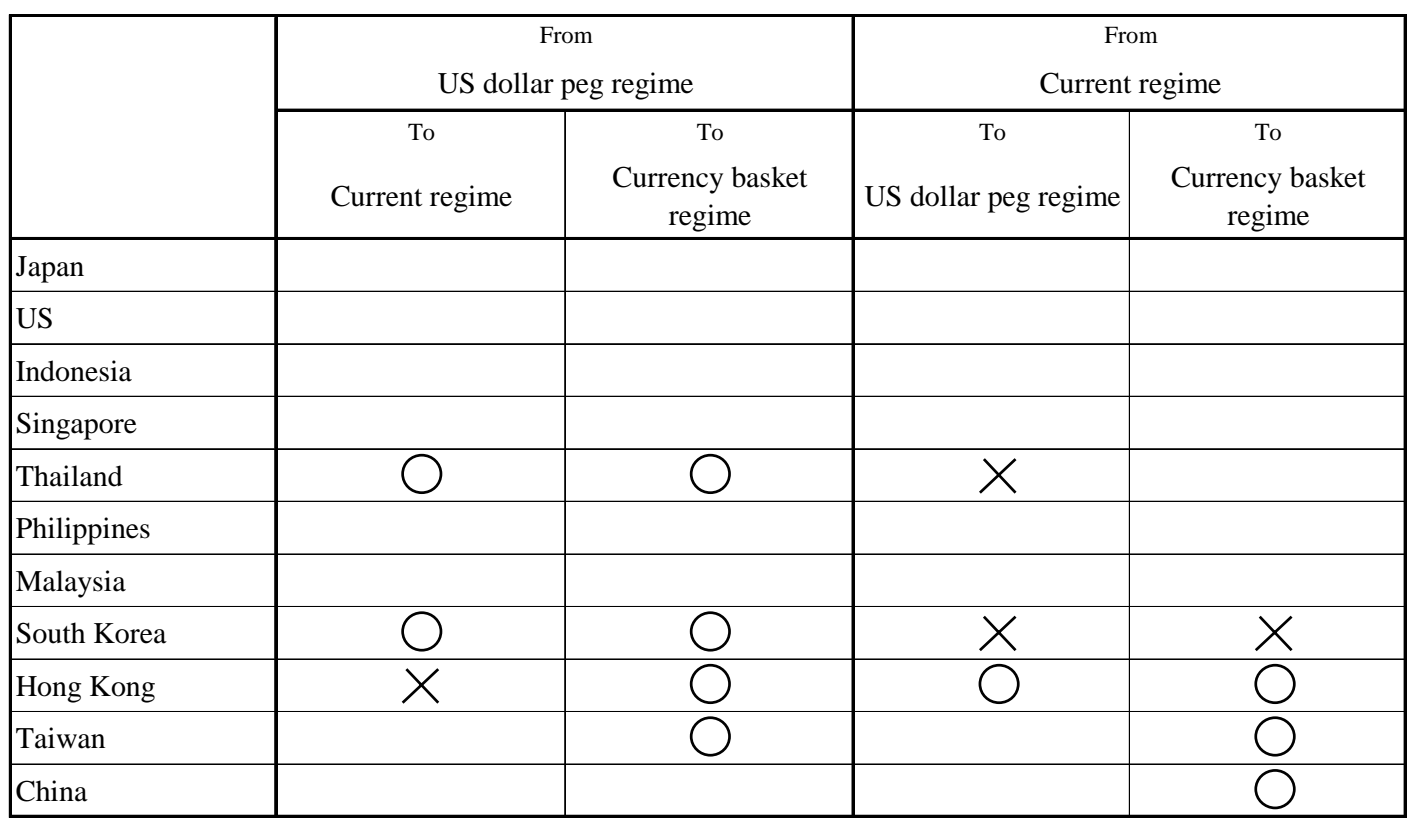

Note: an o indicates that standard deviation of the output gap is reduced more than 5 percent by a regime shift; an $\mathrm{x}$ indicates that standard deviation of the output gap is increased more than 5 percent by a regime shift. 
Table 4

Summary of the Output- Gap Based Evaluations of the Three Policy Regimes

The Demand Shock in the US

a. Standard Deviations of Output Gaps

\begin{tabular}{|l|r|r|r|}
\hline & Current regime & US dollar peg regime & Currecy basket regime \\
\hline Japan & 0.23372 & 0.24281 & 0.23826 \\
US & 1.05417 & 1.06179 & 1.05962 \\
Indonesia & 0.32892 & 0.33647 & 0.33587 \\
Singapore & 0.90062 & 0.91550 & 0.91708 \\
Thailand & 1.23198 & 1.41734 & 1.37685 \\
Philippines & 0.68072 & 0.69297 & 0.69033 \\
Malaysia & 0.71199 & 0.72472 & 0.72243 \\
South Korea & 0.89749 & 0.51084 & 0.45530 \\
Hong Kong & 0.37531 & 0.38864 & 0.39061 \\
Taiwan & 0.69246 & 0.71678 & 0.72042 \\
China & 0.27946 & 0.29117 & 0.29817 \\
\hline
\end{tabular}

b. Significant Changes

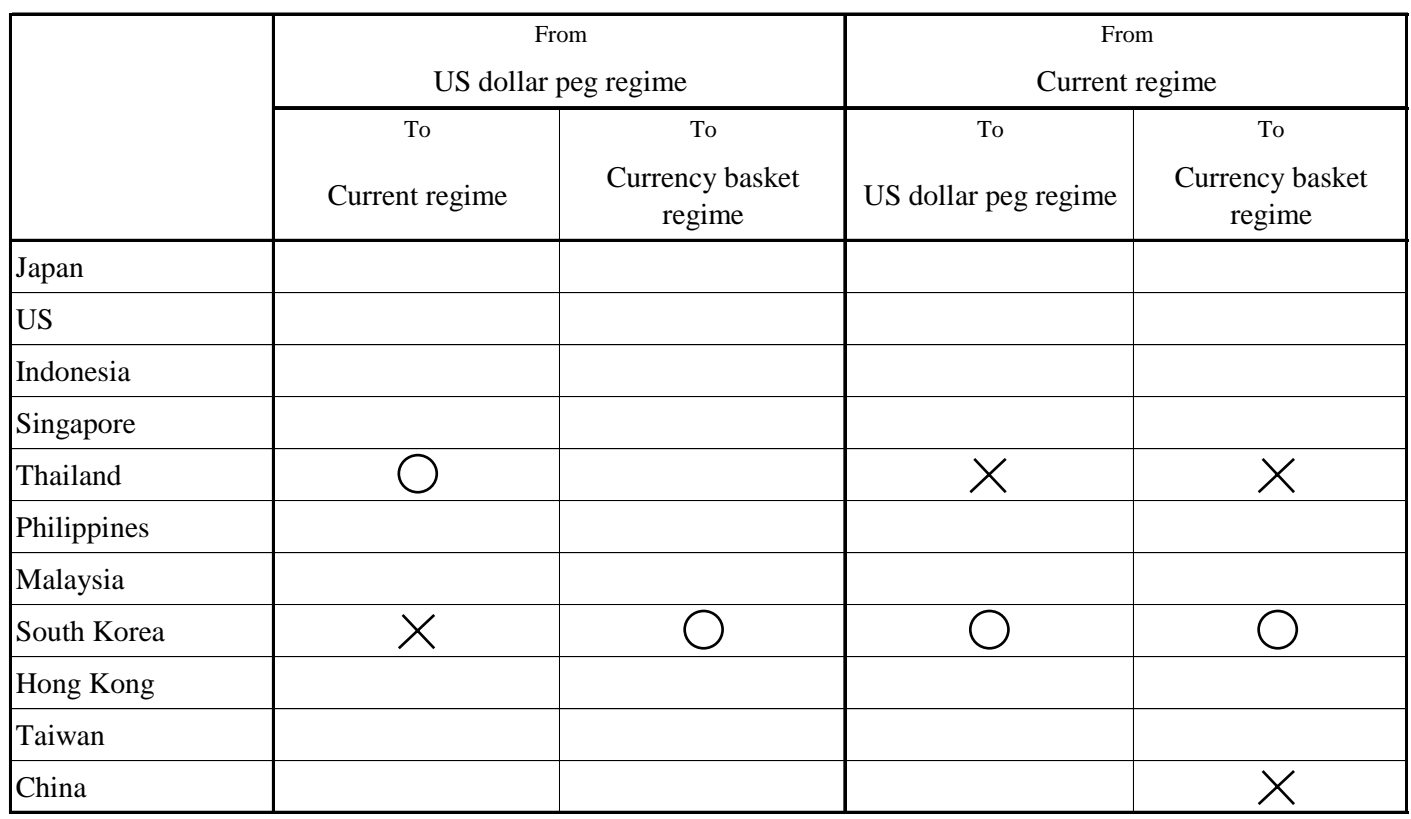

Note: an o indicates that standard deviation of the output gap is reduced more than 5 percent by a regime shift; an $\mathrm{x}$ indicates that standard deviation of the output gap is increased more than 5 percent by a regime shift. 
Table 5

Summary of the Output- Gap Based Evaluations of the Three Policy Regimes

The Risk-Premium Shock in Japan

a. Standard Deviations of Output Gaps

\begin{tabular}{|l|r|r|r|}
\hline & Current regime & US dollar peg regime & Currecy basket regime \\
\hline Japan & 0.00216 & 0.00213 & 0.00200 \\
US & 0.00029 & 0.00030 & 0.00034 \\
Indonesia & 0.00105 & 0.00114 & 0.00080 \\
Singapore & 0.00252 & 0.00364 & 0.00203 \\
Thailand & 0.00434 & 0.00916 & 0.01188 \\
Philippines & 0.00138 & 0.00151 & 0.00122 \\
Malaysia & 0.00190 & 0.00205 & 0.00152 \\
South Korea & 0.00440 & 0.00613 & 0.00810 \\
Hong Kong & 0.00506 & 0.00485 & 0.00060 \\
Taiwan & 0.00604 & 0.00679 & 0.00104 \\
China & 0.00170 & 0.00172 & 0.00097 \\
\hline
\end{tabular}

b. Significant Changes

\begin{tabular}{|c|c|c|c|c|}
\hline & \multicolumn{2}{|c|}{$\begin{array}{c}\text { From } \\
\text { US dollar peg regime }\end{array}$} & \multicolumn{2}{|c|}{$\begin{array}{c}\text { From } \\
\text { Current regime }\end{array}$} \\
\hline & $\begin{array}{c}\text { To } \\
\text { Current regime }\end{array}$ & $\begin{array}{c}\text { To } \\
\text { Currency basket } \\
\text { regime }\end{array}$ & $\begin{array}{c}\text { To } \\
\text { US dollar peg regime }\end{array}$ & $\begin{array}{c}\text { To } \\
\text { Currency basket } \\
\text { regime }\end{array}$ \\
\hline Japan & & D & & 0 \\
\hline US & & $x$ & & $x$ \\
\hline Indonesia & ) & ) & $X$ & ) \\
\hline Singapore & 0 & ) & $x$ & 0 \\
\hline Thailand & 0 & $x$ & $x$ & \\
\hline Philippines & ) & ) & $x$ & \\
\hline Malaysia & 0 & ) & $x$ & ) \\
\hline South Korea & O & $x$ & $x$ & V \\
\hline Hong Kong & & & & \\
\hline Taiwan & 0 & 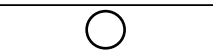 & $x$ & 0 \\
\hline China & & 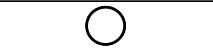 & & 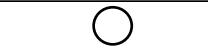 \\
\hline
\end{tabular}

Note: an o indicates that standard deviation of the output gap is reduced more than 5 percent by a regime shift; an $\mathrm{x}$ indicates that standard deviation of the output gap is increased more than 5 percent by a regime shift. 
Table 6

\section{China's Currency Reform}

a. The Demand Shock in China

\begin{tabular}{|c|c|c|c|}
\hline & \multicolumn{2}{|c|}{ Standard Deviations of Output Gaps } & \multirow{2}{*}{ Significant Changes } \\
\hline & De Facto US dollar Peg & Free floating system & \\
\hline Japan & 0.00455 & 0.00765 & X \\
\hline US & 0.00420 & 0.00547 & X \\
\hline Indonesia & 0.00612 & 0.00874 & X \\
\hline Singapore & 0.01865 & 0.02916 & X \\
\hline Thailand & 0.02642 & 0.05679 & X \\
\hline Philippines & 0.01278 & 0.01941 & X \\
\hline Malaysia & 0.01334 & 0.02029 & X \\
\hline South Korea & 0.00796 & 0.02593 & $x$ \\
\hline Hong Kong & 0.02708 & 0.11022 & X \\
\hline Taiwan & 0.01775 & 0.03636 & X \\
\hline China & 0.31787 & 0.29948 & $\bigcirc$ \\
\hline
\end{tabular}

b. The Demand Shock in the US

\begin{tabular}{|l|r|r|c|}
\hline \multirow{2}{*}{} & \multicolumn{2}{|c|}{ Standard Deviations of Output Gaps } & \multirow{2}{*}{ Significant Changes } \\
\cline { 2 - 3 } & De Facto US dollar Peg & Free floating system & \\
\hline Japan & 0.23372 & 0.21022 & $\bigcirc$ \\
US & 1.05417 & 1.03982 & \\
Indonesia & 0.32892 & 0.31073 & $\bigcirc$ \\
Singapore & 0.90062 & 0.83891 & $\bigcirc$ \\
Thailand & 1.23198 & 1.09547 & $\bigcirc$ \\
Philippines & 0.68072 & 0.63719 & $\bigcirc$ \\
Malaysia & 0.71199 & 0.66761 & $\bigcirc$ \\
South Korea & 0.89749 & 0.77308 & $\bigcirc$ \\
Hong Kong & 0.37531 & 0.79792 & $\times$ \\
Taiwan & 0.69246 & 0.67216 & \\
China & 0.27946 & 0.36180 & $X$ \\
\hline
\end{tabular}

c. The Demand Shock in Japan

\begin{tabular}{|l|r|r|c|}
\hline \multirow{2}{*}{} & \multicolumn{2}{|c|}{ Standard Deviations of Output Gaps } & \multirow{2}{*}{ Significant Changes } \\
\cline { 2 - 3 } & De Facto US dollar Peg & Free floating system & \\
\hline Japan & 0.39683 & 0.39581 & \\
US & 0.03705 & 0.03647 & \\
Indonesia & 0.07325 & 0.07250 & \\
Singapore & 0.13637 & 0.13364 & \\
Thailand & 0.24197 & 0.23487 & \\
Philippines & 0.12455 & 0.12302 & \\
Malaysia & 0.11399 & 0.11212 & \\
South Korea & 0.08875 & 0.08519 & \multirow{2}{*}{$\bigcirc$} \\
Hong Kong & 0.05748 & 0.04010 & \\
Taiwan & 0.11264 & 0.10783 & \\
China & 0.05177 & 0.05619 & $X$ \\
\hline
\end{tabular}

Note: an o indicates that standard deviation of the output gap is reduced more than 5 percent by a regime shift;

an $\mathrm{x}$ indicates that standard deviation of the output gap is increased more than 5 percent by a regime shift. 
